\title{
Differential Modulation of Ventral Tegmental Area Circuits by the Nociceptin/Orphanin FQ System
}

\author{
Joseph R. Driscoll, ${ }^{1,2}$ ๑Tanya L. Wallace, ${ }^{1}$ Kasra A. Mansourian, ${ }^{2}$ ○William J. Martin, ${ }^{1}$ and \\ - Elyssa B. Margolis ${ }^{2}$
}

https://doi.org/10.1523/ENEURO.0376-19.2020

${ }^{1}$ BlackThorn Therapeutics, San Francisco, CA 94103 and ${ }^{2}$ UCSF Weill Institute of Neurosciences, Department of Neurology, University of California, San Francisco, San Francisco, CA 94143

\begin{abstract}
The neuropeptide nociceptin/orphanin FQ (N/OFQ) can be released by stressors and is associated with disorders of emotion regulation and reward processing. N/OFQ and its receptor, NOP, are enriched in dopaminergic pathways, and intra-ventricular agonist delivery decreases dopamine levels in the dorsal striatum, nucleus accumbens (NAc), and ventral tegmental area (VTA). We used whole-cell electrophysiology in acute rat midbrain slices to investigate synaptic actions of N/OFQ. N/OFQ was primarily inhibitory, causing outward currents in both immunocytochemically identified dopaminergic (tyrosine hydroxylase positive $(\mathrm{TH}(+))$ ) and non-dopaminergic (TH(-)) VTA neurons; effect at $1 \mu \mathrm{m}$ : $20 \pm 4 \mathrm{pA}$. Surprisingly, this effect was mediated by augmentation of postsynaptic $\mathrm{GABA}_{A} \mathrm{R}$ currents, unlike the substantia nigra pars compacta (SNc), where the $\mathrm{N} / \mathrm{OFQ}$-induced outward currents were $\mathrm{K}^{+}$channel dependent. A smaller population, $17 \%$ of all VTA neurons, responded to low concentrations of N/OFQ with inward currents (10 nm: $-11 \pm 2 \mathrm{pA})$. Following $100 \mathrm{~nm} N /$ OFQ, the response to a second N/OFQ application was markedly diminished in VTA neurons (14 $\pm 10 \%$ of first response) but not in SNc neurons (90 $\pm 20 \%$ of first response). N/OFQ generated outward currents in medial prefrontal cortex (mPFC)-projecting VTA neurons, but inward currents in a subset of posterior anterior cingulate cortex (pACC)-projecting VTA neurons. While N/OFQ inhibited NAc-projecting VTA cell bodies, it had little effect on electrically or optogenetically evoked terminal dopamine release in the NAc measured ex vivo with fast scan cyclic voltammetry (FSCV). These results extend our understanding of the N/OFQ system in brainstem circuits implicated in many neurobehavioral disorders.
\end{abstract}

Key words: dopamine; nociceptin; orphanin FQ; ventral tegmental area; voltage clamp; voltammetry

\section{Significance Statement}

The neuropeptide nociceptin/orphanin FQ (N/OFQ) and its receptor (NOP) are engaged under conditions of stress and are associated with reward processing disorders. Both peptide and receptor are highly enriched in ventral tegmental area (VTA) pathways underlying motivation and reward. Using whole-cell electrophysiology in rat midbrain slices we found: (1) NOPs are functional on both dopaminergic and non-dopaminergic VTA neurons; (2) N/OFQ differentially regulates VTA neurons based on neuroanatomical projection target; and (3) repeated application of N/OFQ produces evidence of receptor desensitization in VTA but not SNc neurons. These results reveal candidate mechanisms by which the NOP system regulates motivation and emotion.

Received September 18, 2019; accepted July 21, 2020; First published August $3,2020$.

T.L.W. and W.J.M. are employees of and shareholders in BlackThorn Therapeutics, which is evaluating BTRX-246040 for the treatment of neurobehavioral disorders. All other authors declare no competing financial interests.
Author contributions: J.R.D., T.L.W., W.J.M., and E.B.M. designed research; J.R.D., K.A.M., and E.B.M. performed research; J.R.D., K.A.M., and E.B.M. analyzed data; J.R.D., T.L.W., W.J.M., and E.B.M. wrote the paper.

This work was supported by a sponsored research agreement from BlackThorn Therapeutics, Inc. to the University of California, San Francisco and the Department of Health and Human Services National Institutes of Health National Institute on Drug Abuse Grant R01 DA042025. 


\section{Introduction}

Nociceptin/orphanin FQ (N/OFQ) and its receptor (NOP) make up a neuropeptide signaling system de-orphaned in 1995 (Meunier et al., 1995; Reinscheid et al., 1995) that is engaged under conditions of stress (Ciccocioppo et al., 2000; Devine et al., 2001; Nicholson et al., 2002; Fernandez et al., 2004; Leggett et al., 2006, 2007; Green et al., 2007; Green and Devine, 2009; Nativio et al., 2012). The NOP is a G-protein coupled seven-transmembrane domain receptor that canonically signals through Gi/o proteins, postsynaptically activating G-protein-coupled inward-rectifying potassium channels (GIRKs), or presynaptically reducing probability of neurotransmitter release via inhibition of $\mathrm{N}$-type calcium channels (Knoflach et al., 1996; Vaughan and Christie, 1996; Hawes et al., 2000; New and Wong, 2002). While amino acid sequence homology has led some to categorize the NOP as an opioid receptor (Bunzow et al., 1994; Mollereau et al., 1994; Wang et al., 1994; Meunier et al., 1995), NOP activation is not blocked by naloxone, a non-selective opioid receptor antagonist that was originally used to classify responses as opioid receptor mediated, blocking activation at $\mu, \delta$, and $\kappa$ opioid receptors (MOPs, DOPs, and KOPs, respectively; Reinscheid et al., 1995, 1996; Gintzler et al., 1997; Mogil and Pasternak, 2001). Furthermore, the known endogenous opioid peptides (dynorphins, enkephalins, and endorphins) do not bind to the NOP, and N/ OFQ does not bind to the MOP, DOP, or KOP (Meng et al., 1996; Sim et al., 1996; Ma et al., 1997). Because of the extensive amino acid sequence homology and these distinct pharmacological properties, N/OFQ and the NOP are most appropriately subclassified as non-classical members of the opioid family (Cox et al., 2015; Toll et al., 2016).

N/OFQ and the NOP are highly enriched in the ventral tegmental area (VTA), dorsal striatum, nucleus accumbens (NAc), medial prefrontal cortex (mPFC), and central nucleus of the amygdala (Neal et al., 1999; Berthele et al., 2003; Parker et al., 2019). The VTA is the major source of dopamine to limbic forebrain regions and plays a key role in brain networks that coordinate motivation and learned appetitive behaviors (Fields et al., 2007). Activity of VTA dopamine neurons is associated with salience and reward prediction, while destruction of these neurons results in motivational deficits (Ungerstedt, 1971; Wise, 2005; Fields et al., 2007; Tsai et al., 2009; Witten et al., 2011; Kim et al., 2012; Morales and Margolis, 2017; Mohebi et al., 2019). Intracerebroventricular (ICV) injections of N/

Acknowledgements: We thank Benjamin J. Snyder and Venkateswaran Ganesh for their technical assistance; Dr. Jing Cheng from the University of California, San Francisco Clinical and Translational Science Institute's Biostatistics Consultation service for feedback on the statistical methods; and Howard L. Fields for helpful comments on this manuscript.

Correspondence should be addressed to Elyssa B. Margolis at elyssa. margolis@ucsf.edu.

https://doi.org/10.1523/ENEURO.0376-19.2020

Copyright $@ 2020$ Driscoll et al.

This is an open-access article distributed under the terms of the Creative Commons Attribution 4.0 International license, which permits unrestricted use, distribution and reproduction in any medium provided that the original work is properly attributed.
OFQ produce a decrease in extracellular dopamine in the dorsal striatum and NAc, and some midbrain putative dopamine cell bodies are inhibited by NOP activation (Murphy et al., 1996; Murphy and Maidment, 1999; Di Giannuario and Pieretti, 2000; Lutfy et al., 2001; Zheng et al., 2002; Vazquez-DeRose et al., 2013).

Dysregulation of the N/OFQ system has been associated with disorders of motivated responding (Civelli and Zhou, 2008), and the N/OFQ system has been investigated as a novel therapeutic target for major depressive disorder and alcohol use disorder (Witkin et al., 2019); however, understanding the involvement of the N/OFQ system in these behaviors remains a challenge. In fact, in some cases, activation and blockade of NOPs paradoxically produce the same behavioral outcomes, for example with alcohol consumption (Kuzmin et al., 2007; Ciccocioppo et al., 2014; Rorick-Kehn et al., 2016) and anxiety-related behaviors (Jenck et al., 1997; Dautzenberg et al., 2001; Gavioli et al., 2002; Fernandez et al., 2004; Kamei et al., 2004; Vitale et al., 2006; Green et al., 2007; Varty et al., 2008). Such observations may be explained by off-target effects of N/OFQ, activation of N/OFQ sensitive neural circuits that compete for behavioral control, or receptor desensitization.

Here, we investigated the basic physiology of N/OFQ responses in VTA neurons to better characterize how N/ OFQ contributes to motivation and reward processing. To confirm that our physiological responses to N/OFQ were because of NOP activation we used the selective NOP antagonist BTRX-246040 (Toledo et al., 2014) to block N/OFQ responses. We observed similar N/OFQ effects on both dopamine and non-dopamine VTA neurons. Importantly, we found that responses to N/OFQ differ between VTA and substantia nigra pars compacta (SNc) neurons in mechanism of inhibition and functional desensitization measures. Furthermore, we found that for VTA neurons, N/OFQ responses vary by the projection target. For example, N/OFQ induced small inward currents preferentially in VTA neurons that project to the posterior anterior cingulate cortex (pACC). In addition, although NAc-projecting cell bodies were inhibited by NOP activation, N/OFQ induced minimal inhibition of dopamine release at terminals in the NAc. Together, these observations indicate that NOP actions vary not only by brain region and neuron subpopulation but also by structural localization within a neuron.

\section{Materials and Methods}

\section{Electrophysiology}

Most experiments were completed in tissue from male Sprague Dawley rats, post-natal day 22-36, except mechanism experiments which were completed in tissue from adult rats $(>200 \mathrm{~g})$. Rats were anesthetized with isoflurane, and brains were removed. The brains were submerged in Ringer's solution containing the following: 119 $\mathrm{mm} \mathrm{NaCl}, 2.5 \mathrm{~mm} \mathrm{KCl}, 1.3 \mathrm{~mm} \mathrm{MgSO}{ }_{4}, 1.0 \mathrm{~mm} \mathrm{NaH}_{2} \mathrm{PO}_{4}$, $2.5 \mathrm{~mm} \mathrm{CaCl}_{2}, 26.2 \mathrm{~mm} \mathrm{NaHCO}_{3}$, and $11 \mathrm{~mm}$ glucose saturated with $95 \% \mathrm{O}_{2}-5 \% \mathrm{CO}_{2}$ and horizontal brain slices (150 $\mu \mathrm{m}$ thick) containing the VTA were prepared using a 
Vibratome (Leica Instruments). Slices were then allowed to recover at $35^{\circ} \mathrm{C}$ for at least $1 \mathrm{~h}$ before recordings were initiated. The same Ringer's solution was used for cutting, recovery, and recording.

Individual slices were visualized under an Olympus BX50WI microscope (Olympus Life Science Solutions) with differential interference contrast optics and near infrared illumination, using an Andor xlon+ camera, and Andor Solis imaging software (Andor Technology Ltd), or under a Zeiss Axio Examiner.D1 with differential interference contrast optics, near infrared illumination, and Dodt contrast, using a monochrome Axiocam 506 (Zeiss International). Whole-cell patch-clamp recordings were made at $33^{\circ} \mathrm{C}$ using 2.5-4 $\mathrm{M} \Omega$ pipettes containing the following: $123 \mathrm{~mm}$ K-gluconate, 10 mм HEPES, $0.2 \mathrm{~mm}$ EGTA, $8 \mathrm{~mm} \mathrm{NaCl}, 2$ mm MgATP, and $0.3 \mathrm{~mm} \mathrm{Na}_{3} \mathrm{GTP}, \mathrm{pH}$ 7.2, osmolarity adjusted to $275 \mathrm{mOsm}$. Biocytin $(0.1 \%)$ was added to the internal solution for post hoc identification.

Recordings were made using an Axopatch 1-D (Molecular Devices), filtered at $2 \mathrm{kHz}$, and collected at $20 \mathrm{kHz}$ using IGOR Pro (Wavemetrics) or an IPA amplifier with SutterPatch software (Sutter Instrument) filtered at $1 \mathrm{kHz}$ and collected at $10 \mathrm{kHz}$. Liquid junction potentials were not corrected during recordings. Hyperpolarization-activated cation currents $\left(I_{h}\right)$ were recorded by voltage clamping cells and stepping from -60 to $-40,-50,-70,-80,-90,-100,-110$, and $-120 \mathrm{mV}$. The $I_{\mathrm{h}}$ magnitude was measured as the difference between the initial response to the voltage step after the capacitive peak and the final current response.

Pharmacology experiments were completed in voltageclamp mode $(\mathrm{V}=-60 \mathrm{mV})$ to measure changes in membrane current. Series resistance was monitored online by measuring the peak of the capacitance transient in response to a $-4 \mathrm{mV}$ voltage step applied at the onset of each sweep. Input resistance was measured using the steady state response to the same voltage step. Upon breaking into the cell, at least $10 \mathrm{~min}$ was allowed for the cell to stabilize and for the pipette internal solution to dialyze into the cell. Drugs were applied via bath perfusion at a flow rate of $2 \mathrm{~mL} / \mathrm{min}$ or pressure ejection using a SmartSquirt micro-perfusion system (AutoMate Scientific) coupled to a $250-\mu \mathrm{m}$ inner diameter tubing outlet positioned nearby the recorded cell (within $\sim 200 \mu \mathrm{m}$ ). N/OFQ (1 nM to $10 \mu \mathrm{M})$ was bath applied (5-7 min) or pressure injected (2 min) only after a 5-min stable baseline was achieved. Responses were similar to the two forms of N/ OFQ application at the same concentrations. For instance, at $100 \mathrm{~nm}$, bath application $10.1 \pm 1.5 \mathrm{pA}, n=21$; pressure ejection $9.8 \pm 2.1 \mathrm{pA}, n=12$. As there was no statistical difference in the mean amplitude of response for bath application and pressure injection, the results were combined for the analysis. Any cell that showed drift or did not maintain a consistent baseline current for the full 5-min period was removed from the analysis. All experiments where repeated N/OFQ applications are reported, such as the desensitization experiments, were completed with bath application. To test that observed N/ OFQ-mediated effects were specific to NOP, the selective NOP antagonist BTRX-246040 (100 nM) was applied for 10 min before N/OFQ.
For iontophoresis experiments, the holding current was set to $-50 \mathrm{mV}$ to increase the driving potential for $\mathrm{Cl}^{-}$. GABA (100 mM, pH adjusted to 4.9 with $37 \% \mathrm{HCl}$ ) was prepared daily and the GABA-containing pipette was positioned $\sim 50 \mu \mathrm{m}$ away from the recorded neuron. Negative retention current (approximately $-35 \mathrm{nA}$ ) was applied to the GABA pipette, interrupted by positive ejection current pulses $(100 \mathrm{~ms})$ once every $30 \mathrm{~s}$, with the intensity adjusted so that the response amplitude was in the range of $100-300 \mathrm{pA}$.

Stock solutions of drugs were made in advance, stored at $-20^{\circ} \mathrm{C}$, and diluted into artificial CSF (aCSF) immediately before application. N/OFQ was obtained from Tocris and diluted to a $100 \mu \mathrm{m}$ stock solution in $\mathrm{ddH}_{2} \mathrm{O}$. Stock BTRX-246040 was obtained from BlackThorn Therapeutics and dissolved in dimethylsulfoxide (10 mM).

\section{Retrograde tracer injections}

Male Sprague Dawley rats, 21-100 d old, were anesthetized with isoflurane. A glass pipette (30- to $50-\mu \mathrm{m}$ tip) connected to a Nanoject II/Nanoliter 2000 microinjector (Drummond Scientific Co) was stereotaxically placed in the $\mathrm{mPFC}$ [from bregma: anteroposterior (AP), +2.6 mm; mediolateral (ML), $\pm 0.8 \mathrm{~mm}$; ventral (DV), $-4.0 \mathrm{~mm}$ from skull surface], the pACC (AP, $1.6 \mathrm{~mm}$; ML, $\pm 0.6 \mathrm{~mm}$; V, $-3.5 \mathrm{~mm}$ ), or the NAc (AP, $+1.5 \mathrm{~mm}$; $\mathrm{ML}, \pm 0.8 \mathrm{~mm}$; V, $-6.7 \mathrm{~mm}$ ). Neuro-Dil ( $7 \%$ in ethanol; Biotium) was slowly injected, $50.6 \mathrm{~nL}$ per side. Animals were allowed to recover for 5-7d, while the retrograde tracer transported back to the cell bodies. On the day of recording, the experimenter was blind to the location of retrograde tracer injection (mPFC, pACC, or NAc), and slices were prepared as above. Projection neurons were chosen by selecting cells observed as labeled using epifluorescent illumination. All injection sites were histologically confirmed by a third party blind to the electrophysiology results to avoid bias. $\mathrm{N} / \mathrm{OFQ}$ responses were analyzed before unblinding. Animals with improper injection placements or significant diffusion outside of the target region were rejected.

\section{Immunohistochemistry}

Slices were preblocked for $2 \mathrm{~h}$ at room temperature in PBS with $0.2 \%$ BSA and $5 \%$ normal goat serum, then incubated at $4^{\circ} \mathrm{C}$ with a rabbit anti-TH polyclonal antibody (1:100; EMD Millipore, RRID: AB_390204). Slices were then washed thoroughly in PBS with $0.2 \%$ BSA before being agitated overnight at $4^{\circ} \mathrm{C}$ with $\mathrm{Cy} 5$ anti-rabbit secondary antibody (1:100; Jackson ImmunoResearch, RRID: AB_2534032) and FITC streptavidin $(6.5 \mu \mathrm{L} / \mathrm{ml})$. Sections were rinsed and mounted on slides using Bio-Rad Fluoroguard Antifade Reagent mounting media and visualized with an Axioskop FS2 Plus microscope with an Axiocam MRm running Neurolucida (MBF Biosciences). Neurons were only considered $\mathrm{TH}(-)$ if there was no colocalization of biocytin with $\mathrm{TH}$ signal and the biocytin soma was in the same focal plane as other $\mathrm{TH}(+)$ cell bodies. Primary antibodies were obtained from Millipore Bioscience Research Reagents or Millipore, secondary antibodies were 
obtained from Jackson ImmunoResearch, and all other reagents were obtained from Sigma Chemical.

\section{Fast scan cyclic voltammetry (FSCV)}

Male Sprague Dawley rats, 21-26 d old, or Th::Cre transgenic rats (Witten et al., 2011), 46-51 d old at the time of virus injection, were used in these studies. Th:: Cre rats were injected with the Cre-dependent ChR2expressing virus (AAV2-Ef1a-DIO-hChR2(H134R)mCherry, titer $5.1 \times 1012$ viral particles $/ \mathrm{mL}$, UPenn viral core) bilaterally into the VTA $500 \mathrm{~nL}$ per side (AP, $-5.3 \mathrm{~mm}$; ML, $\pm 0.4 \mathrm{~mm}$; DV,$-8.2 \mathrm{~mm}$ from bregma). Five weeks later, coronal slices $(400 \mu \mathrm{m})$ containing the NAc were prepared for voltammetry measurements. The use of Cre dependent ChR2 expression allowed selective optical control of VTA dopamine terminals in the NAc.

Extracellular dopamine release was achieved using either electrical (in wild-type Sprague Dawley rats) or 470$\mathrm{nm}$ light (in Th::Cre rats) stimulation. Stimulation parameters were the same for both electrical and optical stimulation $(10 \mathrm{~Hz}$, two pulses, $4 \mathrm{~ms})$. Electrochemical recordings were made using carbon fiber electrodes fabricated from T-650 carbon fiber $(7 \mu \mathrm{m}$ diameter, gift from Leslie Sombers, NCSU) that was aspirated into a borosilicate glass capillary $(0.6 \times 0.4 \mathrm{~mm}$ or $1.0 \times 0.5 \mathrm{~mm}$ in diameter, King Precision Glass Inc.) and pulled using a PE-22 puller (Narishige). Carbon fiber electrodes were positioned $80 \mu \mathrm{m}$ into the tissue either between the bipolar tips of the stimulating electrode or directly in front of an optical fiber connected to an LED emitting $470 \mathrm{~nm}$ light (7-10 $\mathrm{mW}$ ). The potential of the carbon fiber electrode was held at $-0.4 \mathrm{~V}$ relative to the $\mathrm{Ag} / \mathrm{AgCl}$ reference electrode. A triangle wave form was applied to the carbon fiber driving the potential from -0.4 to $+1.3 \mathrm{~V}$ and back to $-0.4 \mathrm{~V}$ at a rate of $400 \mathrm{~V} / \mathrm{s}$, at $60 \mathrm{~Hz}$ for conditioning and $10 \mathrm{~Hz}$ for data collection. Data were collected with a WaveNeuro FSCV potentiostat (Pine Research) using HDCV acquisition software package (freely available through UNC Department of Chemistry). HDCV Acquisition Software was used to output the electrochemical waveform and for signal processing (background subtraction, signal averaging, and digital filtering; four-pole Bessel filter, $2.5 \mathrm{kHz}$ ). Dopamine release was stimulated at 2 min intervals for electrical stimulation and 3 min intervals for optical stimulation. The difference in stimulation intervals was to decrease rundown of the dopamine release signal that can be particularly strong in optical experiments as reported in (Bass et al., 2013; O'Neill et al., 2017). Mean background currents from $1 \mathrm{~s}$ of data before stimulation were removed by subtraction of cyclic voltammograms for each trial.

\section{Data analysis}

For electrophysiology, effects of N/OFQ were statistically evaluated in each neuron by binning data into $30 \mathrm{~s}$ data points and comparing the last eight binned predrug points to the last eight binned points during drug application using Student's unpaired $t$ test. To evaluate the output of this analysis approach, we performed a subsequent sliding window analysis on this classified data from $\mathrm{TH}(+)$ neurons that were tested with $10 \mathrm{~nm}$ N/OFQ (Extended Data Fig. 1-1). The results of this analysis are consistent with this classification scheme identifying drug responses and a lack of contamination by drift in individual recordings. The summary effect sizes reported here are the differences between the mean of this baseline 4 min window and the mean of the $I_{\text {holding }}$ during the last $4 \mathrm{~min}$ of drug application. For within cell comparisons of N/OFQ responses, responses were compared with a Student's paired $t$ test; $p<0.05$ was required for significance in all analyses. Differences between neuron populations were tested using two-tailed permutation analyses unless otherwise indicated. Violin plots were constructed by calculating the kernel density estimate, made using a Scott estimator for the kernel bandwidth estimation. The kernel size was determined by multiplying the Scott bandwidth factor by the SD of the data within each bin. Each individual violin plot was normalized to have an equal area under the curve. Time course figures are averages of the binned current traces for all cells time locked to the start of drug application. $\mathrm{EC}_{50}$ was estimated by fitting the concentration response data with the Hill equation. Results are presented as mean and SEM. Custom code created for analyses here are publicly available at https://osf.io/c8gu7/?view_only= 24595243ef6d44d5974442b23dda0b1d.

\section{Results}

\section{N/OFQ effects on holding current in VTA dopamine and non-dopamine neurons}

To test the postsynaptic responses of VTA neurons to N/OFQ, we made ex vivo whole-cell voltage-clamp recordings $\left(\mathrm{V}_{\mathrm{m}}=-60 \mathrm{mV}\right)$. N/OFQ application changed the holding current in $70 \%(60 / 86)$ of neurons tested in the VTA (10 nм; 86 neurons from 59 rats; Fig. $1 A, B$ ). The majority of responses were relatively small outward currents ( $73 \%$ of responsive neurons, $44 / 60 ; 51 \%$ of all neurons tested, 44/86; mean response magnitude $=15 \pm 2 \mathrm{pA}$; Fig. $1 D$; examples of small responses provided in Extended Data Fig. 1-2A-C). In many cases, the holding current returned to baseline during N/OFQ washout, as in Figure $1 A$; however, in some cases, we observed only partial recovery. Using post hoc immunocytochemistry, we analyzed TH content in each histologically recovered neuron and found that N/OFQ inhibited both confirmed dopamine and non-dopamine neurons in similar proportions [of 44 inhibited neurons from 38 rats, 26 neurons from 23 rats were identified: $\mathrm{TH}(+)$ : 12/26; $\mathrm{TH}(-)$ : 14/26]. The magnitudes of responses were also similar between confirmed dopamine and non-dopamine neurons $[\mathrm{TH}(+): 12 \pm 2 \mathrm{pA}$ $(n=12) ; \mathrm{TH}(-): 9 \pm 2 \mathrm{pA}(n=14) ; p=0.3$ two-tailed permutation test; Fig. $1 C$ ]. The $\mathrm{EC}_{50}$ for these outward currents is in the $\mathrm{nM}$ range $(8 \pm 6 \mathrm{nM}$; Fig. $1 E)$.

To confirm responses were due to activation of the NOP, we tested whether these inhibitions were blocked by the selective NOP antagonist BTRX-246040. In neurons responding to N/OFQ with an outward current, 


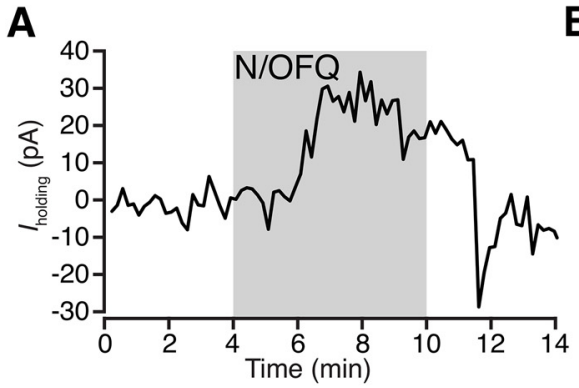

$\begin{array}{ll}\text { B Overall Response } & \text { Inhibition Response } \\ \text { Rate: } & \text { Rate: }\end{array}$ Rate: No Response
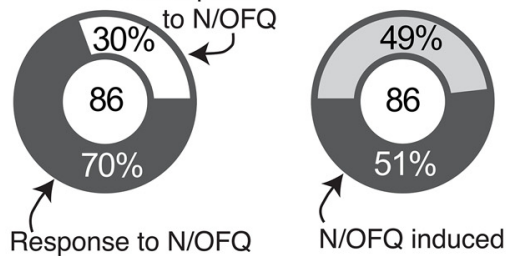

N/OFQ induced
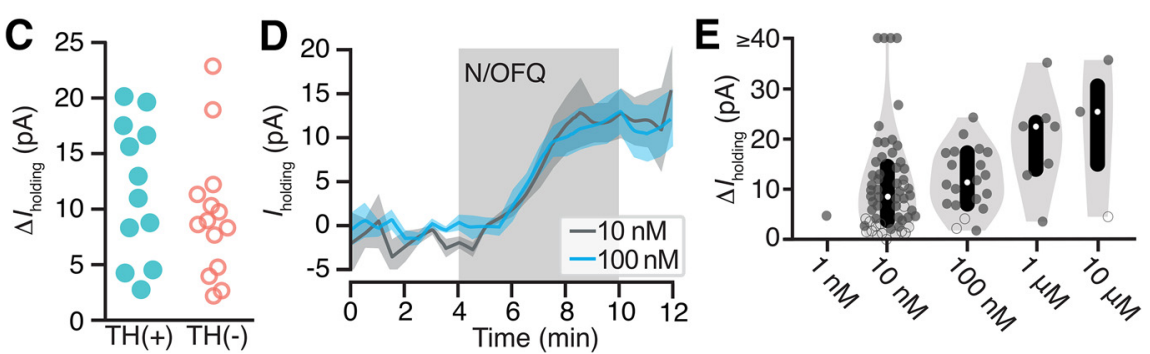

Figure 1. N/OFQ-induced outward currents in a subset of VTA neurons. $\boldsymbol{A}$, Example voltage-clamp recording $\left(\mathrm{V}_{\text {clamp }}=-60 \mathrm{mV}\right)$ of a VTA neuron that responded to N/OFQ with an outward current. $\boldsymbol{B}$, Across recordings in neurons from control rats, the majority of VTA neurons responded to $10 \mathrm{nM}$ N/OFQ application (60 out of 86 neurons responded). Forty-four out of 60 responses were outward currents. C, A subset of recorded neurons were recovered following whole-cell recording and immunocytochemically identified for TH content, a marker for dopamine neurons. Outward currents of similar magnitudes were observed in $\mathrm{TH}(+)$ and $\mathrm{TH}(-) \mathrm{neurons}$. $\boldsymbol{D}$, The mean \pm SEM time courses and maximal effects of bath application of 10 and $100 \mathrm{~nm}$ N/OFQ were similar. $\boldsymbol{E}$, Concentration response relationship for VTA neurons showing a positive change, both significant (solid circle) and not significant (open circle), in holding current with N/OFQ application (gray markers include all neurons with a change $>0 \mathrm{pA}$; median shown in white dots; black bars show 25th and 75th percentiles; 1 nм: $n=1 / 6 ; 10 \mathrm{nм}: n=55 / 86 ; 100 \mathrm{nм}: n=20 / 25 ; 1 \mu \mathrm{M}: n=7 / 8 ; 10 \mu \mathrm{M}: n=3 / 4$ ).

BTRX-246040 (100 nm) was applied for 10 min and then N/ OFQ was applied a second time in the presence of the antagonist. BTRX-246040 consistently blocked N/OFQ-induced outward currents (baseline $10 \mathrm{~nm} \mathrm{N/OFQ} \mathrm{response:} 14 \pm$ $3 \mathrm{pA}$; N/OFQ response in BTRX-246040: $-1 \pm 2 \mathrm{pA} ; n=15$; 14 rats; paired $t$ test: $p=0.0005$; Fig. 2).

We also observed a subpopulation of neurons that responded to N/OFQ application with a small inward current, consistent with an excitatory effect (10 nM mean response $=-16 \pm 6 \mathrm{pA}$; Fig. $3 A, B)$. Inward currents were observed in $\sim 25 \%(15 / 60)$ of the neurons that were responsive to N/OFQ (10 nM) and $17 \%$ of all 10 nM-tested VTA neurons (15/86; 15 neurons from 14 rats; Fig. 3C,D; examples of small responses provided in Extended Data Fig. 1-2D-F). Among five neurons responding to N/OFQ with an inward current and immunocytochemically identified, 40\% (2/5) were $\mathrm{TH}(+)$ and $60 \%(3 / 5)$ were $\mathrm{TH}(-)$ (two-tailed permutation test: $p=0.6$; Fig. $3 E$ ). These N/OFQ evoked excitatory responses were only observed at low concentrations ( $\leq 100$ nм; Fig. 3D); at higher concentrations, only outward currents were observed (Figs. 1E, 3D). The neurons showing this excitatory response to N/OFQ were topographically intermixed with VTA neurons that responded to N/OFQ with an outward current (Fig. 3F).

\section{Concentration-dependent desensitization of NOPs}

Given the inconsistencies in the reports of behavioral effects of NOP agonists and antagonists, we tested whether N/OFQ causes rapid NOP desensitization at moderate doses. We observed a concentration-dependent diminished response to a second application of $\mathrm{N} /$ OFQ when the first application of N/OFQ was $\geq 100 \mathrm{~nm}$ ( $n=12$ neurons from 12 rats; paired $t$ test $p=0.00003$; Fig. $4 A, B)$. This is consistent with NOP desensitization, and observed in both $\mathrm{TH}(+)$ and $\mathrm{TH}(-)$ neurons (Fig. 4B). In contrast, following administration of $10 \mathrm{~nm}$ N/OFQ, no significant difference in response was observed between the second and first applications $(n=10$ neurons from 8 rats; paired $t$ test $p=0.13$; Fig. $4 C, D$ ). Therefore, desensitization occurs at moderate N/OFQ concentrations in the VTA.
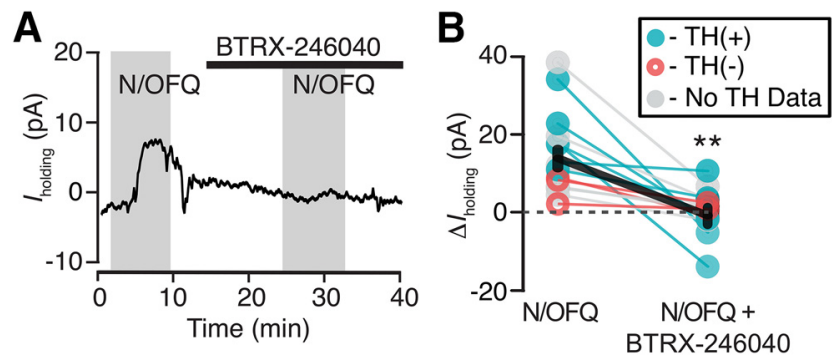

Figure 2 BTRX-246040 consistently blocks N/OFQ-induced currents. $\boldsymbol{A}$, Example recording of a N/OFQ (10 nM) responsive neuron where the selective NOP antagonist BTRX-246040 (100 nM) blocked the response to a subsequent N/OFQ application. $\boldsymbol{B}$, BTRX-246040 blocked N/OFQ responses across VTA neurons, including both $\mathrm{TH}(+)$ and $\mathrm{TH}(-)$ neurons $(n=6$ and 3 , respectively; $n=6$ no TH data; mean \pm SEM in black); $* * p<0.01$. 

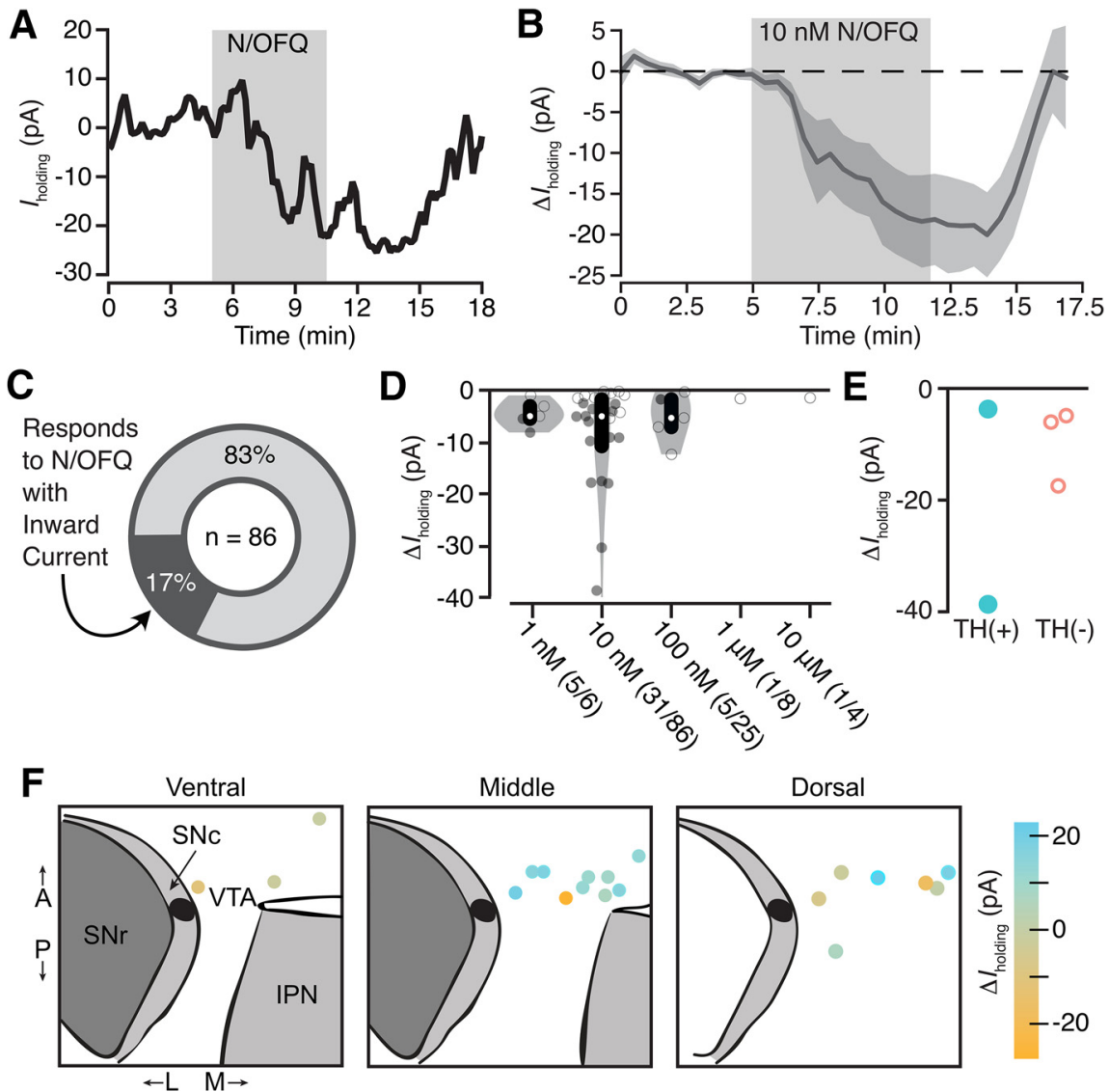

Figure 3 Low-dose N/OFQ-induced small inward currents in a subset of VTA neurons. $\boldsymbol{A}$, Example voltage-clamp recording ( $\mathrm{V}_{\text {clamp }}$ $=-60 \mathrm{mV}$ ) of a VTA neuron that responded to N/OFQ with an inward current. $\boldsymbol{B}$, The mean \pm SEM time course across neurons with inward currents shows the onset of this response is time locked to the initiation of drug application $(n=15)$. C, Across all VTA neurons from control rats that were tested for $10 \mathrm{~nm}$ N/OFQ responses, $17 \%$ responded with a significant inward current. $\boldsymbol{D}$, Concentration response data for each neuron showing a negative change, both significant (filled circle) and not significant (open circle), in holding current with N/OFQ application (gray markers include all neurons with a change $<0$ pA; median shown in white dots; black bars show 25th and 75th percentiles). Significant inward currents were observed at 10 nm, while higher concentrations only generated outward currents (Fig. 1E). E, Inward currents were observed in both immunocytochemically identified TH(+) and TH $(-)$ neurons. $\boldsymbol{F}$, Locations of VTA recordings show that neurons that responded to N/OFQ with inward and outward currents were intermixed.

\section{N/OFQ inhibits VTA neurons and SNc neurons via different cellular mechanisms}

We investigated the mechanism underlying the outward currents produced by N/OFQ in VTA neurons. These experiments were completed in adult animals to ensure we measured the mature mechanisms of N/OFQ actions. The most common mechanism by which Gi/o coupled receptors, including the NOP, generate somatodendritic electrophysiological inhibition is by activation of GIRKs. First, we tested whether the $\mathrm{K}^{+}$channel blocker $\mathrm{BaCl}_{2}(100 \mu \mathrm{m})$ prevented N/OFQ-induced outward currents. Surprisingly, $\mathrm{BaCl}_{2}$ did not prevent the outward currents induced by N/ OFQ at either $100 \mathrm{~nm}$ (Fig. 5A) or $10 \mathrm{~nm}$ [Fig. 5B; one tailed permutation analysis comparing all $10 \mathrm{~nm}$ N/OFQ VTA observations from p22-p36 animals in Fig. $1(n=86)$ to $10 \mathrm{~nm}$ $\mathrm{N} / \mathrm{OFQ}$ observations in the presence of $100 \mu \mathrm{M} \mathrm{BaCl} 2$ $(n=7), p=0.2$; each recording with a outward current response $>1.5 \mathrm{pA}$ is shown in Extended Data Fig. 5-1A-C]. We next tested whether a cocktail of synaptic blockers including the $\mathrm{Na}^{+}$channel blocker tetrotodoxin (TTX; $500 \mathrm{~nm}$ ), the AMPA receptor (AMPAR) blocker 6,7-dinitroquinoxaline-2,3(1H,4H)-dione (DNQX; $10 \mu \mathrm{M})$, and the $\mathrm{GABA}_{A} \mathrm{R}$ antagonist bicuculline $(10 \mu \mathrm{M})$ would alter N/OFQ responses. Interestingly, while this cocktail did not significantly change the mean of VTA neuron N/OFQ responses [Fig. $5 C$; the one recording with a outward current response $>1.5 \mathrm{pA}$ is shown in Extended Data Fig. 5-1D; two-tailed permutation analysis comparing the means of all $10 \mathrm{~nm}$ N/OFQ VTA observations from p22-p36 animals in Fig. $1(n=86)$ to $10 \mathrm{~nm}$ N/OFQ observations in the synaptic blocker cocktail $(n=9)$, $p=0.16)]$, only one out of nine neurons responded to $10 \mathrm{~nm}$ $\mathrm{N} / \mathrm{OFQ}$ with an outward current under these conditions (Extended Data Fig. 5-1D), raising the possibility of a difference in the proportion of neurons with this type of response in the inhibitor cocktail. The SD of the distribution of N/OFQ responses in the presence of the inhibitor cocktail was significantly reduced, also consistent with the possibility this treatment diminished N/OFQ responses (one tailed permutation analysis comparing the SDs of all $10 \mathrm{~nm}$ N/OFQ VTA observations from p22-p36 animals in Fig. 1; SD = 
A

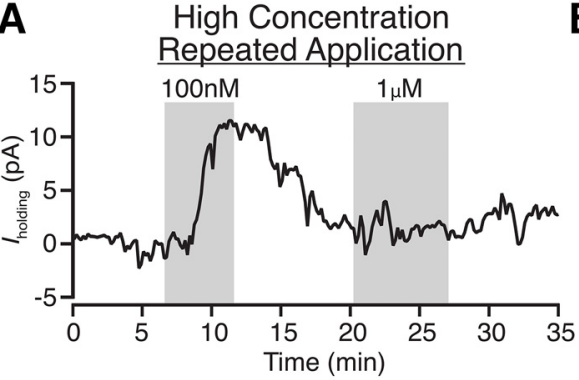

C

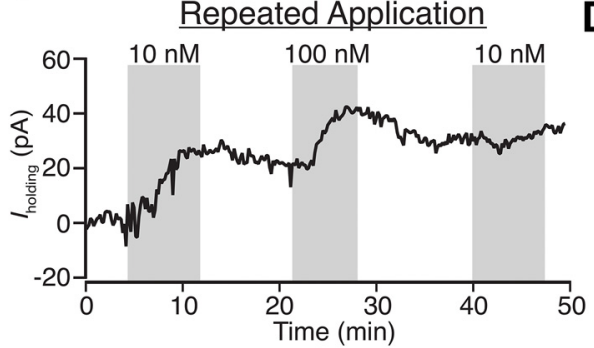

Low Concentration

Repeated Application
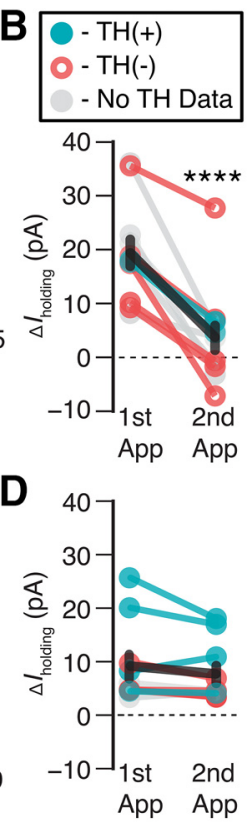

Figure 4. Moderate concentrations of N/OFQ cause functional desensitization in VTA neurons. $\boldsymbol{A}$, Example voltage-clamp recording $\left(V_{\text {clamp }}=-60 \mathrm{mV}\right)$ where $100 \mathrm{~nm}$ is sufficient to prevent a subsequent response to $1 \mu \mathrm{m}$ application of N/OFQ. B, A summary across VTA neurons where the first N/OFQ application was $\geq 100$ $\mathrm{nM}$, the response to the second application was consistently smaller $(* * * * p=0.00003)$, in both $\mathrm{TH}(+)$ and $\mathrm{TH}(-)$ neurons $(n=2$ and 5 , respectively; $n=5$ no TH data). $\boldsymbol{C}$, Example voltage-clamp recording $\left.\mathrm{V}_{\text {clamp }}=-60 \mathrm{mV}\right)$ showing that $10 \mathrm{~nm} \mathrm{~N} / \mathrm{OFQ}$ does not impair responses to subsequent N/OFQ application. In the same cell, 100 nM did prevent additional responding. $\boldsymbol{D}$, Summary across VTA neurons shows similar magnitudes of responses to the second application of N/OFQ when the first application was $10 \mathrm{~nm}[p=0.13$; $\mathrm{TH}(+)$ $n=4, \mathrm{TH}(-) n=2$, $\mathrm{TH}$ no data $n=2]$.

$20.36 \mathrm{pA}$, variance $=414.53 \mathrm{pA}, n=86$ ) to $10 \mathrm{~nm}$ N/OFQ observations in the synaptic blocker cocktail $(S D=6.27 \mathrm{pA}$, variance $=39.27 \mathrm{pA}, n=9$ ), $p=0.03 ; 10 \mathrm{~nm}$ N/OFQ observations in $\mathrm{BaCl}_{2}(\mathrm{SD}=9.34 \mathrm{pA}$, variance $=87.27 \mathrm{pA}, n=9)$, $p=0.15]$. Since the cocktail of synaptic blockers did not yield a significant change in the mean of the responses, this was most consistent with both outward and inward current responses being diminished. Focusing on the outward currents, if these blockers decreased the outward current responses to N/OFQ, the simplest possible mechanisms are via an inhibition of AMPAR signaling, via an increase in $\mathrm{GABA}_{A} R$ signaling, or via a non-GIRK-dependent effect of a substance released by action potential activity in the slice. We previously found that in stressed animals, DOP activation in the VTA postsynaptically increases GABA $_{A} R$ signaling in VTA neurons (Margolis et al., 2011), and there is evidence for tonic $\mathrm{GABA}_{\mathrm{A}} \mathrm{R}$ currents in VTA neurons (Darnieder et al., 2019). On the other hand, spontaneous glutamate release in the VTA seems insufficient to support generating an apparent outward current when glutamate release is inhibited (Koga and Momiyama, 2000; Margolis et al., 2005; Xiao et al., 2009). Therefore, we tested whether N/ OFQ affects $G_{A B A} R$ signaling in the VTA and whether this might account for N/OFQ-induced changes in holding current. We iontophoretically applied GABA in the presence of $\mathrm{GABA}_{B} \mathrm{R}$ blockade (CGP35348, $30 \mu \mathrm{M}$ ) to measure $G A B A_{A} R$ responses and to bypass any potential presynaptic terminal effects. We not only found that $100 \mathrm{~nm} N / O F Q$ increased the amplitude of $\mathrm{GABA}_{A} \mathrm{R}$ responses (Fig. $5 D, E$ ), the effect on iontophoresed GABA currents was proportional to the change in holding current induced by N/OFQ (Fig. $5 E$ ), across both inward and outward currents induced by N/OFQ, making it likely that $G_{A B A_{A}} R$ signaling underlies both inward and outward currents induced by N/OFQ application to VTA neurons.

That N/OFQ-induced outward currents are because of augmentations of $G A B A_{A} R$-mediated current rather than activation of a $\mathrm{K}^{+}$current was particularly surprising because it was previously reported that N/OFQ activates a $\mathrm{K}^{+}$channel in VTA neurons (Zheng et al., 2002). Zheng and colleagues also reported larger average outward currents compared with our dataset and did not observe desensitization with repeated applications of $300 \mathrm{~nm}$ N/OFQ, inconsistent with our findings here. As a positive control to test that $100 \mu \mathrm{M} \mathrm{BaCl}_{2}$ was sufficient to block $\mathrm{K}^{+}$-mediated effects in our preparation, and in an attempt to resolve these discrepancies, we completed additional recordings in the SNc, just lateral to the VTA (Fig. 5/). First, we tested whether repeated application of $100 \mathrm{~nm}$ N/OFQ to SNc neurons resulted in less desensitization than we observed in VTA neurons. In fact, the response to the second $100 \mathrm{~nm}$ N/OFQ application was not statistically different from the response to the first application in SNc neurons, in contrast to VTA neurons (Fig. 5F, G; twotailed paired $t$ test, $p=0.5, n=5$ ). Therefore, we used a within cell design to compare the N/OFQ response in control aCSF and in $100 \mu \mathrm{M} \mathrm{BaCl}_{2}$. Blocking $\mathrm{K}^{+}$channels significantly reduced the magnitude of N/OFQ responses in SNc neurons (Fig. $5 \mathrm{H}$; one-tailed paired $t$ test, $p=0.003, n=5)$. Together, these observations indicate that $\mathrm{BaCl}_{2}$ was fully capable of blocking GIRKmediated N/OFQ effects in our recording conditions and suggest that the differences between our observations and those previously reported may be related to recording location (Fig. 5/).

\section{N/OFQ effects on VTA neurons vary with projection target}

As described above, we observed heterogeneity in responses of VTA neurons to N/OFQ. Given that other pharmacological responses of VTA neurons, including to KOP activation (Ford et al., 2006; Margolis et al., 2006), vary with projection target, we investigated whether the $\mathrm{N} /$ OFQ responses would be more consistent within subpopulations of VTA neurons that share a projection target. Accordingly, we recorded N/OFQ (10 nM) responses in VTA neurons that were retrogradely labeled by tracer injections into mPFC, pACC, or medial NAc (Fig. 6A,B). Recordings were conducted with the investigator blinded to the injection site.

The majority of mPFC-projecting VTA neurons, 67\% (8/ 12), were significantly inhibited by $N / O F Q$, responding with an outward current $(11 \pm 3 \mathrm{pA}$; eight responsive neurons from six rats; Fig. $6 D, E$ ). No N/OFQ-induced inward 

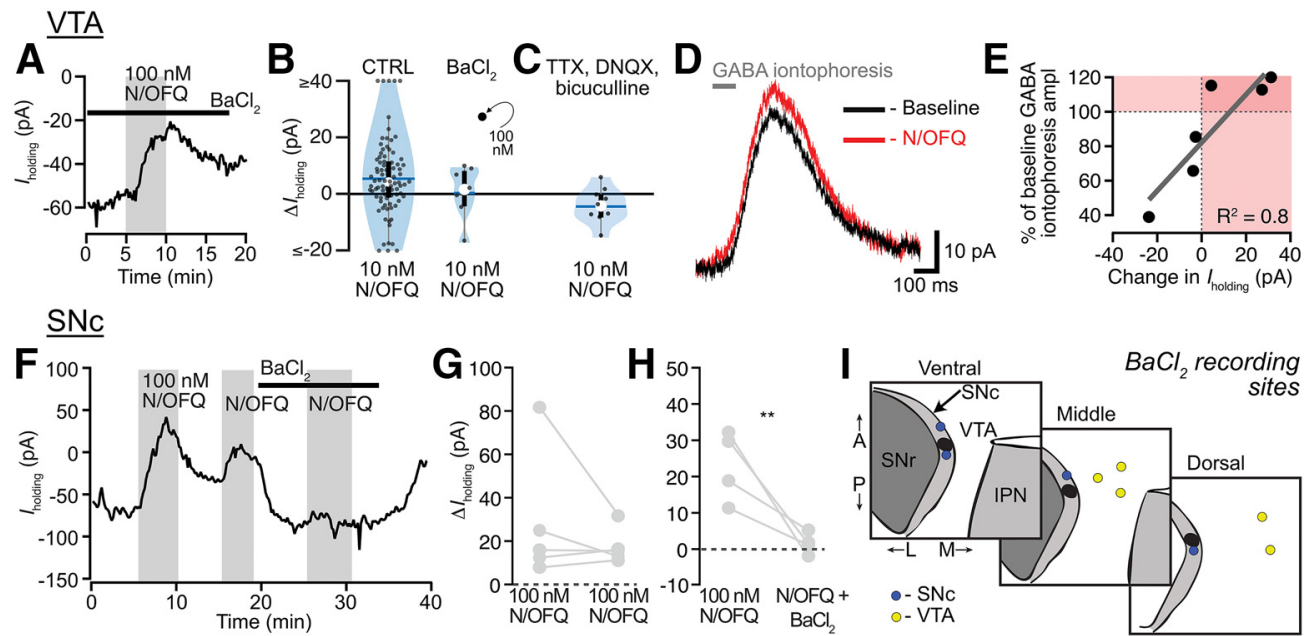

Figure 5. GABA $A_{A}$ s, rather than GIRKs, mediate N/OFQ effects in VTA neurons. $\boldsymbol{A}$, Example recording showing that the $\mathrm{K}^{+}$channel blocker $\mathrm{BaCl}_{2}(100 \mu \mathrm{M})$ did not prevent a N/OFQ-induced outward current in a VTA neuron. $\boldsymbol{B}$, Blue violin plots representing the distributions of responses of VTA neurons to $10 \mathrm{~nm} \mathrm{N/OFQ} \mathrm{(blue} \mathrm{horizontal} \mathrm{line}=$ mean; white circle $=$ median; black rectangle $=25$ th and 75 th percentiles). Gray circles show individual responses (single $100 \mathrm{~nm}$ experiment in black). There was no difference detected between the distribution of control observations in p22-p36 from adult animals in the presence of $\mathrm{BaCl}_{2}$ have a similar distribution (one tailed permutation analysis of the means, $p=0.2$ ). $C$, Recordings in $500 \mathrm{~nm} T \mathrm{TX}, 10 \mu \mathrm{M} D N Q X$, and $10 \mu \mathrm{m}$ bicuculline to block synaptic activity, AMPARs, and GABA $A_{A}$ s, respectively, showed an almost complete elimination of outward currents in VTA neurons in response to N/ OFQ (two-tailed permutation analysis of the means, $p=0.16$; one tailed permutation analysis of the $\mathrm{SDs}, p=0.03$ ). $\boldsymbol{D}$, Example recording of $\mathrm{GABA}_{A} \mathrm{R}$-mediated iontophoretic responses to GABA (in $30 \mu \mathrm{M}$ CGP35348 to block GABA $\mathrm{B}_{B}$ ) showing an augmentation of response amplitude in response to $100 \mathrm{~nm}$ N/OFQ. $\boldsymbol{E}$, Summary of the N/OFQ (100 nM)-induced change in iontophoretic response versus change in I holding, showing both inward and outward N/OFQ-induced currents are highly correlated with N/OFQ-induced changes in iontophoresis amplitude $(t=3.904 ; \mathrm{df}=4 ; p=0.02)$. $\boldsymbol{F}$, Example recording in a SNc neuron showing repeated responses to high-concentration (100 nM) $\mathrm{N} / \mathrm{OFQ}$, and blockade of the N/OFQ response by $\mathrm{BaCl}_{2}$. G. Summary data from SNc neurons showing minimal desensitization in control experiments with repeated within cell N/OFQ applications at high concentration. $\boldsymbol{H}$, Summary data from $\mathrm{SNc}$ neurons show that $\mathrm{BaCl}_{2}$ prevents a second response to N/OFQ, indicating that in the $\mathrm{SNc}, \mathrm{N} / \mathrm{OFQ}$ outward currents are mediated by $\mathrm{K}^{+}$channels; $* * p<0.01$. $\boldsymbol{I}$, Recording locations for VTA and SNc recordings where N/OFQ was tested in the presence of $\mathrm{BaCl}_{2}$.

currents were observed in mPFC-projecting neurons. Five mPFC-projecting neurons were recovered and processed for $\mathrm{TH}$ immunoreactivity (Fig. 6C,E); two were $\mathrm{TH}(+)$, and three were $\mathrm{TH}(-)$; all of these responded to N/OFQ with an outward current (Fig. 6E).

VTA projections to different cortical targets, including the pACC, arise from largely separate VTA neurons (Chandler et al., 2013). The pACC-projecting neurons are concentrated in different parts of the VTA, and fewer of them are dopaminergic compared with the projection to mPFC (Breton et al., 2019). Interestingly, $67 \%$ of the VTA neurons comprising this projection responded to N/OFQ with an inward current (4/6 inward current, $-24 \pm 12 \mathrm{pA}$, $1 / 6$ outward current, from four rats; Fig. $6 D, E$ ). These N/ OFQ excited, pACC-projecting VTA neurons included both $\mathrm{TH}(+)$ and $\mathrm{TH}(-)$ cells (Fig. $6 E$ ).

Half of NAc-projecting VTA neurons (7/14) responded to N/OFQ with outward currents $(9 \pm 1 \mathrm{pA}$, seven responsive neurons from seven rats; Fig. $6 D, E$ ). No inward currents were observed in this projection. Of the seven NAcprojecting neurons that responded to N/OFQ, two were confirmed $\mathrm{TH}(+)$ and three were $\mathrm{TH}(-)$ (Fig. 6E). Together, these data indicate that similar N/OFQ inhibitory effects occur in VTA neurons that project to MPFC and NAc, but these effects are opposed to those on VTA projections to pACC, many of which responded to N/OFQ with an inward current.

\section{N/OFQ has minimal effect on terminal dopamine release in the NAC}

ICV or intra-VTA N/OFQ decreases dopamine levels in the NAc (Murphy et al., 1996; Murphy and Maidment, 1999). Consistent with this result, we found that N/OFQ directly inhibits a subset of the NAc-projecting VTA dopamine somata. N/OFQ may also inhibit dopamine release in the NAc at the terminals; to test whether NOPs on dopamine terminals in the NAc also contribute to an N/OFQinduced decrease in NAc dopamine levels, we used FSCV to detect changes in stimulated dopamine release in NAc slices (Fig. 7A). In tissue from control SD rats (nine rats), we stimulated dopamine release with a bipolar electrode. In a second set of animals, to limit stimulation to dopaminergic axons, we expressed ChR2 in Th::Cre rats and stimulated with 470-nm light pulses (nine rats). In these preparations, repeated electrical, and especially optical, stimulation can cause rundown in evoked dopamine release over time (Bass et al., 2013; O'Neill et al., 2017). To minimize this rundown as much as possible, we increased the intervals between light stimulations to $3 \mathrm{~min}$. Where recordings were stable, effects of $10 \mathrm{~nm}$ N/OFQ, $100 \mathrm{~nm}$ $\mathrm{N} / \mathrm{OFQ}$, and $1 \mu \mathrm{m} \mathrm{U} 69,593$ were sequentially tested. At 10 nм N/OFQ, approximately the $\mathrm{EC}_{50}$ of the outward currents recorded at VTA somata, there was no change in the peak FSCV response to either electrically or light evoked dopamine release (electrically evoked dopamine release: 


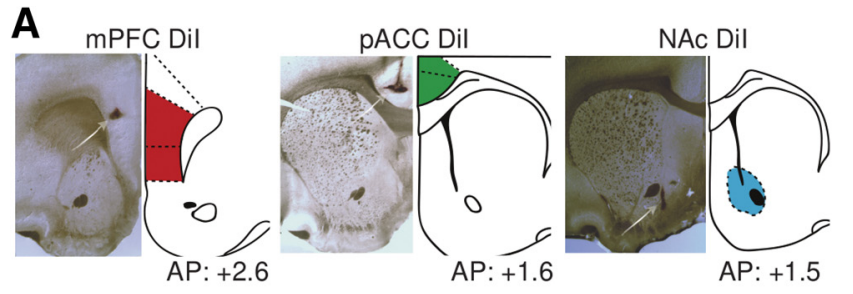

B

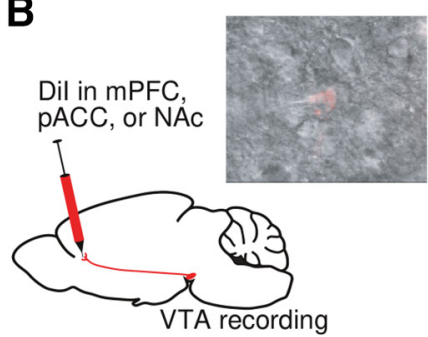

C biocytin

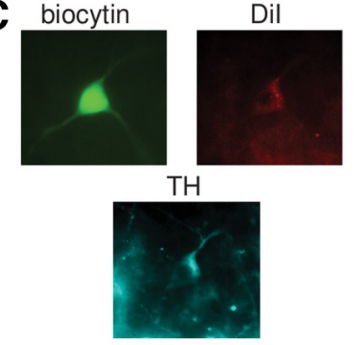

D

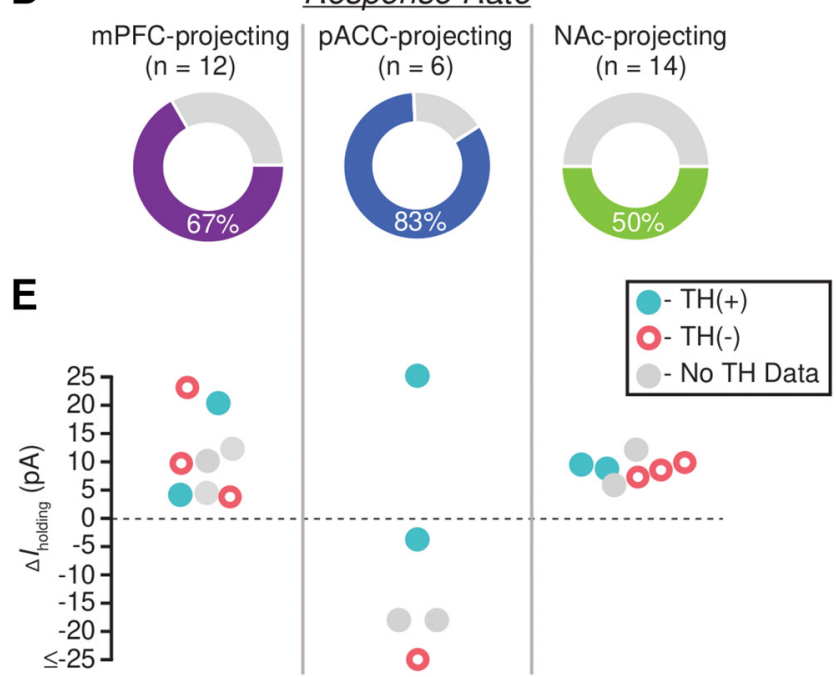

Figure 6. N/OFQ effects in VTA neurons vary with projection target. $\boldsymbol{A}$, For each retrograde tracer injection site, example histology photograph showing Dil localization (left) and mirrored, modified rat brain atlas schematic (right; Paxinos and Watson, 1997). B, Cartoon showing the experimental approach: $7 \mathrm{~d}$ before recording, the retrograde tracer Dil was stereotaxically injected into mPFC, pACC, or medial NAc. Dil neurons were identified during whole-cell recordings (inset). C, Example image of a neuron filled with biocytin during recording (green), the retrograde tracer (red), and was immunocytochemically identified as $\mathrm{TH}(+)$ (turquoise). $\boldsymbol{D}$, The overall percentage of neurons that responded to N/OFQ was greatest among pACCprojecting neurons and lowest among NAc-projecting neurons. $\boldsymbol{E}$, Graph of magnitudes of significant N/OFQ responses, showing that only pACC-projecting neurons respond to N/OFQ with an inward current.

$93 \pm 4 \%$ of baseline, $n=9$ slices from 9 rats: linear mixed effects model, $z=-1.3, p=0.2$; optically evoked dopamine release: $94 \pm 10 \%$ of baseline, $n=5$ from 5 rats: linear mixed effects model, $z=-0.5, p=0.6$; Fig. $7 A, B)$. We detected a small but significant decrease in evoked dopamine release in response to $100 \mathrm{~nm} \mathrm{~N} / \mathrm{OFQ}$ (electrically evoked dopamine release: $88 \pm 7 \%$ of baseline, $n=11$ from 9 rats: linear mixed effects model, $z=-2.1, p=0.04$; optically evoked dopamine release: $74 \pm 4 \%$ of baseline, $n=17$ from 9 rats: linear mixed effects model, $z=-7.2$, $p<0.001$; Fig. $7 B$ ). Consistent with previous studies (Bass et al., 2013; O'Neill et al., 2017), it is possible that this small decrease was driven, at least in part, by rundown of ChR2-driven dopamine release. As a positive control, we applied the selective KOP agonist U69,593 (1 $\mu \mathrm{M})$, previously shown to inhibit dopamine release in the NAc (Di Chiara and Imperato, 1988a,b; Werling et al., 1988; Spanagel et al., 1992; Ebner et al., 2010; Karkhanis et al., 2016), at the end of each experiment, on top of $\mathrm{N} /$ OFQ since these drug responses were minimal. U69,593 caused a substantial decrease in stimulated dopamine release (electrical: $53 \pm 5 \%$ of baseline (in N/OFQ), $n=15$ : linear mixed effects model, $z=-8.9, p<0.001$; optical: $49 \pm 3 \%$ of baseline (in N/OFQ), $n=17$ : linear mixed effects model, $z=-13.9, p<0.001$; Fig. $7 B$ ). Therefore, the direct NOP modulation of this dopaminergic circuit occurs at a lower concentration and may be stronger in the somadendritic region where the terminals in the NAc are relatively insensitive to NOP activation. These results contrast with the KOP control of these neurons, which strongly inhibits release at the NAc dopamine terminals but does not directly hyperpolarize the cell bodies of these neurons (Margolis et al., 2006; Fig. 7C).

\section{Discussion}

The results presented here demonstrate that N/OFQ affects both dopaminergic and non-dopaminergic VTA neurons, through activation of the NOP, and in the majority of neurons causes inhibitory outward currents. N/OFQ effects in these neurons were blocked by the NOP-selective antagonist BTRX-246040, confirming its action at NOP. Importantly, neuronal responses to N/OFQ in VTA neurons desensitized at concentrations $\geq 100 \mathrm{~nm}$. In addition to providing a basic characterization of the range of postsynaptic N/OFQ responses in VTA neurons, we demonstrated differential responding of subsets of VTA neurons to NOP activation related to projection target: mPFC-projecting and NAc-projecting VTA neurons responded to N/ OFQ with outward currents (inhibitory), while most pACCprojecting VTA neurons responded with inward currents (excitatory). Within the dopaminergic projection to the NAc, although N/OFQ caused outward currents at the somatodendritic region of these neurons, release at the terminals was not inhibited by NOP activation. Together, these data show that N/OFQ effects in VTA neurons differ depending on their projection target and that at higher concentrations of N/OFQ only inhibitions are observed, followed by desensitization of NOP function.

Unexpectedly, a small population of neurons in the VTA, both $\mathrm{TH}(+)$ and $\mathrm{TH}(-)$, responded to low concentrations of N/OFQ with an inward current, consistent with excitation. This finding presents a novel mechanism by which N/OFQ could selectively activate specific VTA circuits, while inhibiting the majority of VTA outputs. Inward currents were observed in most VTA neurons projecting to the pACC, but not those projecting to the NAc or $\mathrm{mPFC}$, consistent with this circuit-selection proposition. 

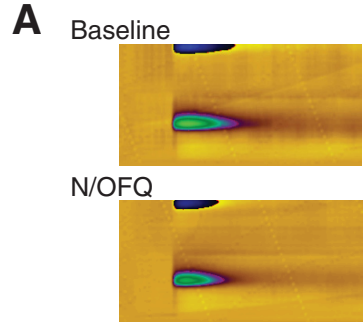

U69593
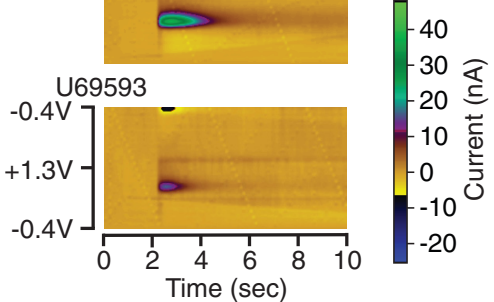

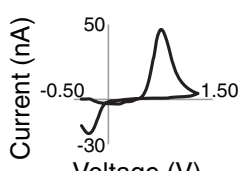

Voltage (V)

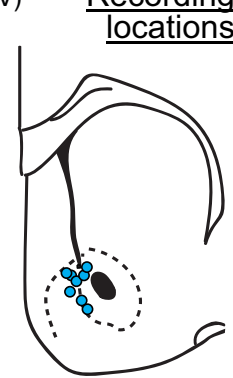

B Stimulation: - E- Electrical $\square$-Optogenetic

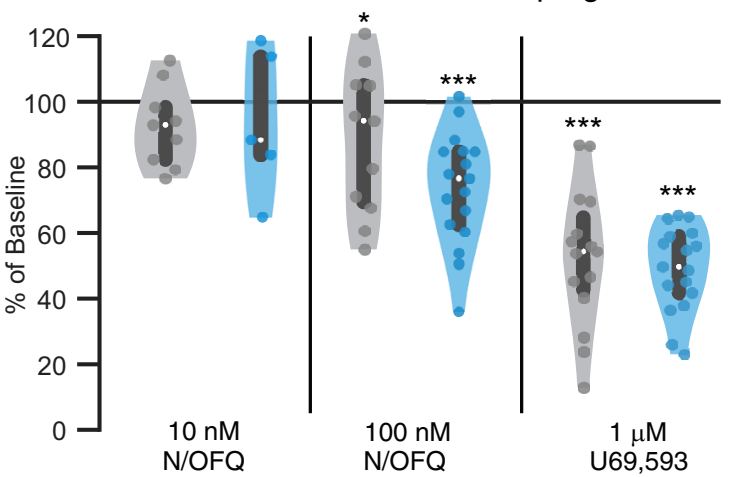

C
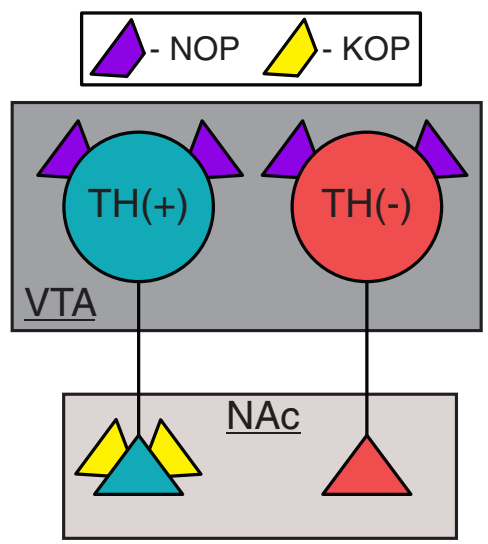

Figure 7. N/OFQ minimally inhibits dopamine release at NAc terminals. We used FSCV in acute, coronal slices containing the $\mathrm{NAc}$ to test for N/OFQ effects on terminal release of dopamine. Dopamine release was evoked in slices from control rats with bipolar electrodes locally in the NAc. Recordings were made on the NAc shell-core border. Alternatively, to limit stimulation to dopamine axons, Th::Cre rats were injected with (AAV2-Ef1aDIO-hChR2(H134R)-mCherry) in the VTA at least four weeks before recordings, and 470-nm light pulses were used to stimulate dopamine release. $\boldsymbol{A}$, Example color plots of FSCV measurement of electrically evoked dopamine release. Inset, top, Background subtracted cyclic voltammogram at peak of putative dopamine release. Inset, bottom, Locations of FSCV recordings in schematic of coronal section of rat brain AP: +1.5 $\mathrm{mm}$ (Paxinos and Watson, 1997). B. Serial application of $10 \mathrm{~nm}$ then $100 \mathrm{~nm}$ N/OFQ was applied to the slice; $10 \mathrm{~nm}$ did not
The fact that this effect was only observed at low concentrations indicates that very robust N/OFQ release into the VTA, on the other hand, would likely have a broad inhibitory effect on the vast majority of VTA neurons, regardless of circuit. Although NOPs are generally thought to couple to Gi/o and inhibit neural activity, some exceptions to this coupling have been reported for the related opioid receptors. Activation of postsynaptic MOP or DOP results in a $\mathrm{Ca}_{\mathrm{v}} 2.1$ channel-dependent depolarization in subsets of VTA neurons (Margolis et al., 2014, 2017). Further, the MOP agonist DAMGO increases $\mathrm{Ca}_{\mathrm{v}} 2.1$ currents in cerebellar Purkinje neurons (legorova et al., 2010) and morphine activates adenylyl cyclase in the corpus striatum and olfactory bulb (Puri et al., 1975; Onali and Olianas, 1991). While this is the first report of N/OFQ-mediated excitations in an acute brain slice preparation, intracellular increases in $\mathrm{Ca}^{2+}$ have been observed in a cultured human neuroblastoma cell line in response to N/OFQ in the presence of the cholinergic agonist carbachol (Connor et al., 1996). Therefore, while there are few reports of excitatory actions of N/OFQ, the observation is not unprecedented.

We also found that NOP activation signals through the canonical GIRK pathway in the SNc; however, in the VTA, N/OFQ outward currents were mediated by augmentation of $G_{A B A} R$ currents. This action via GABA $A_{A} R$ is consistent with many of the N/OFQ-induced outward current sizes observed here being small, since our holding potential was only $10 \mathrm{mV}$ depolarized from the calculated $\mathrm{Cl}^{-}$reversal potential. We note that while our population sampling was conducted in p22-p35 rats (Fig. 1), our mechanism experiments were conducted in adults, raising the possibility that there might be some differences in the populations of neurons. We have previously found similar electrophysiological properties and dopamine D2 receptor and KOP receptor pharmacological responses in VTA neurons recorded from p35 compared with adult (>p60) rats (Margolis et al., 2008), and others have also reported mature firing patterns, biophysical properties, and dopamine D2 receptor GIRK-mediated responses in SNc dopamine neurons early in postnatal development (Tepper et al., 1990; Walsh et al., 1991; Wang and Pitts, 1995). Since the range of N/OFQ responses in the control population is relatively large, small changes in the distribution of N/OFQ responses because of the blockers would be difficult to detect statistically. That said, among

\section{continued}

induce a significant change in either electrically or light evoked dopamine release; $100 \mathrm{~nm}$ had a small but significant inhibitory effect on electrically $(p=0.04)$ or light $(p<0.001)$ evoked dopamine release in the NAc (linear mixed effects model). Following N/OFQ measures, without washout, we added the KOP agonist U69,593 (1 $\mu \mathrm{M})$, which inhibited evoked dopamine release. White dots represent median values and gray bars represent 25th and 75th percentiles. C, Summary diagram shows the contrast between NOP and KOP function in NAc-projecting VTA dopamine neurons. While NOP activation inhibits the somatodendritic compartment only, KOP-induced inhibition is limited to dopaminergic axon terminals in these neurons. Further, NOP activation inhibits NAc-projecting non-dopaminergic VTA cell bodies, which are insensitive to KOP activation. 
SNc recordings, a small sample size with more homogeneous N/OFQ responses was sufficient to demonstrate a GIRK contribution to N/OFQ responses in adult rats. Thus, while age differences are a noted caveat regarding the statistical comparisons made here, prior studies show other GPCR responses in these neurons appear mature in p22-p35 rats.

While both GIRK activation and the $\mathrm{GABA}_{\mathrm{A}} \mathrm{R}$ dependent mechanism generated outward currents in our experimental preparation, the physiological consequences of these neural populations using different signaling pathways in vivo may vary. For instance, activating a GIRK will always cause a hyperpolarization, while increasing the $G_{A B A} R$ conductance will only occur when there is concurrent activation of NOPs and $\mathrm{GABA}_{A}$ Rs. Further, the N/ $O F Q$-induced neural inhibition requiring $G_{A B A} R$ activation depends on the $\mathrm{Cl}^{-}$reversal potential, which may be altered by a variety of behavioral states including pain, morphine treatment, stress, or alcohol exposure (Coull et al., 2003; Hewitt et al., 2009; Ferrini et al., 2013; Ostroumov et al., 2016; Santos et al., 2017). The N/OFQ response may even be excitatory in the absence of $G_{A B} A_{A} R$ activation, since blocking $G_{A B} A_{A} R$ s seemed to increase the proportion of neurons in which we observed inward currents in response to N/OFQ (Fig. 5C).

In the VTA, neurons treated with a higher concentration of N/OFQ $(\geq 100 \mathrm{~nm})$ no longer responded to subsequent applications of N/OFQ in the VTA. This finding indicates that N/OFQ may act as a functional antagonist at the NOP by desensitizing these responses when higher concentrations of N/OFQ are present. Interestingly, we did not observe significant NOP desensitization in SNc neurons. NOP function is therefore apparently different from postsynaptic responses to agonists at the MOP and DOP in VTA neurons, where repeated application of saturating concentrations of selective agonists generate responses of similar magnitudes (Margolis et al., 2014, 2017). The apparent NOP desensitization we observed in the VTA is consistent with previous studies showing that high concentrations or repeated sustained exposure to NOP agonists causes desensitization in cell culture (Connor et al., 1996; Mandyam et al., 2000, 2002; Thakker and Standifer, 2002). In addition, NOPs internalize fairly rapidly (Spampinato et al., 2001, 2002; Corbani et al., 2004; Zhang et al., 2012) at the same concentrations that we observed desensitization. In vivo, N/OFQ administration can result in dose-dependent performance changes in behavioral spatial memory, locomotor, and anxiety tasks, with low-concentration N/OFQ having opposite effects compared with high doses (Florin et al., 1996; Jenck et al., 1997; Sandin et al., 2004). One possible explanation for these opposing behavioral outcomes is that N/ OFQ may be acting as an agonist at low concentrations and a functional antagonist at high concentrations in some brain regions. An alternative possibility is that brain regions like the SNc that have less desensitization drive behavioral responses to high doses of N/OFQ, where brain regions like the VTA that show more desensitization mostly contribute to behavioral responses to lower N/OFQ doses.

$\mathrm{N} / \mathrm{OFQ}$ inhibited both dopamine and non-dopamine neurons in the VTA that project to the NAc. This finding is consistent with the observation that N/OFQ administered
ICV or into the VTA results in a decrease in extracellular dopamine in the NAc (Murphy et al., 1996; Murphy and Maidment, 1999). A prominent proposal in the literature is that a decrease in NAc dopamine produces aversion (McCutcheon et al., 2012). Therefore, one would expect ICV injection of N/OFQ to be aversive. However, this manipulation generates no response in the place conditioning paradigm (Devine et al., 1996). On the other hand, optogenetic or chemogenetic stimulation of N/OFQ containing inputs to the VTA can be aversive and decrease reward seeking (Parker et al., 2019). One possible explanation for this lack of clear motivational effect is the combination of inhibition of both dopamine and non-dopamine neurons: dopamine and non-dopamine neurons originating in the VTA synapse onto different types of neurons in the NAc, therefore affecting behavior in different ways. For instance, VTA glutamate neurons synapse onto parvalbumin containing interneurons in the NAc and optogenetic activation of these NAc-projecting glutamate neurons is aversive (Qi et al., 2016). Activation of NAc-projecting VTA GABA neurons causes a pause in cholinergic interneuron activity (Brown et al., 2012). These neurons modulate associative learning but are insufficient to drive preference or aversion independently (Collins et al., 2019) and do not appear to contribute to the detection of aversive gustatory stimuli (Robble et al., 2020). N/OFQ inhibition of dopamine, GABA, and glutamate neurons projecting to the NAc, therefore, may result in no net hedonic value and a lack of preference in a place preference paradigm. Further, various reports indicate that decreasing activity at dopamine receptors in the NAc via microinjections of antagonists does not produce aversion (Josselyn and Beninger, 1993; Baker et al., 1996, 1998; Morutto and Phillips, 1998; Laviolette and van der Kooy, 2003; Fenu et al., 2006; Spina et al., 2006; but see Shippenberg et al., 1991), and aversive outcomes can even be observed following manipulations that increase dopamine levels in the NAc (Devine et al., 1993b; Shippenberg and Bals-Kubik, 1995). Add to this the N/ OFQ effects on other circuits following ICV injection, including other VTA neurons, and the possibility that the most robust, long-lasting effect is receptor desensitization at higher doses of agonist, together make it potentially less surprising that ICV N/OFQ was not reported to generate aversion.

N/OFQ's effect on the VTA to NAc circuit provides an interesting point of comparison for how the NOP may be functionally distinct from the structurally related KOP. In vivo, systemic or ICV administration of N/OFQ or a KOP agonist each causes a decrease in extracellular dopamine in the NAc (Di Chiara and Imperato, 1988a,b; Devine et al., 1993a; Murphy et al., 1996; Murphy and Maidment, 1999). However, these two receptors function very differently in the dopamine neurons that project to the NAc. We show here that N/OFQ inhibits VTA cell bodies that project to the NAc but has little effect on the dopamine terminals within the NAc. KOP activation, on the other hand, has no effect on the cell bodies of NAc-projecting VTA dopamine neurons, but strongly inhibits dopamine release at the terminals in the NAc (Margolis et al., 2006; Britt and McGehee, 2008; Fig. 5C). One implication for this 
organization is that whether or not the respective endogenous peptides, N/OFQ and dynorphin, affect NAcprojecting dopamine neurons will depend on the brain region of peptide release. There is also evidence for dopamine release in the NAc that is independent of action potential firing in midbrain dopamine neurons (Cachope et al., 2012; Mohebi et al., 2019). In this organization of differential receptor effects localized to somadendritic regions versus terminals, dynorphin has control over this terminal activity while N/OFQ does not. Together, these observations bring into focus the critical importance of understanding precisely where receptors are functional in brain circuits and their specific actions at each site.

We found opposing effects of N/OFQ on the VTA projections to $\mathrm{MPFC}$ and $\mathrm{pACC}$, which may contribute to the reported N/OFQ impact on behavioral measures associated with cortical dopamine function such as working memory, learning, and behavioral flexibility (Tzschentke, 2001; Winter et al., 2009; Gonzalez et al., 2014; Puig et al., 2014; Huang et al., 2019; Ott and Nieder, 2019). Our results also show that the non-dopamine VTA projections to cortical regions are affected by N/OFQ as well; while the majority of the VTA neurons that project to these cortical regions are not dopaminergic (Breton et al., 2019), little is currently known regarding their contribution to behavior. Preclinical studies show that ICV administration of N/OFQ impairs working memory (Hiramatsu and Inoue, 1999) and associative learning and memory (Goeldner et al., 2009), while blocking NOP with an antagonist or genetic knock-out enhances both working memory and learning (Noda et al., 1999; Jinsmaa et al., 2000; Nagai et al., 2007). How such a break on learning and memory by endogenous N/OFQ contributes to normal behavioral adaptation, and whether dopamine or other VTA outputs play a role, remains to be determined. One provocative possibility is that it is this degradation of working memory function that is the primary mechanism underlying the lack of place conditioning in response to central N/OFQ, rather than that this treatment is affectively neutral. This interpretation is consistent with work showing that N/OFQ blocks opioid induced conditioned place preference yet has no effect on opioid self-administration (Walker et al., 1998; Sakoori and Murphy, 2004).

The results of this study extend our understanding of the NOP system's biology and provide considerations for additional investigation into NOP function within limbic circuits. These findings clarify that strong NOP desensitization occurs in neurons at moderate concentrations of the endogenous agonist N/OFQ. Importantly, not only does the nature of the NOP response vary with the projection target of VTA neurons, but the NOP function is largely sequestered to the somatodendritic compartment of VTA dopamine neurons that project to the NAc, demonstrating two different kinds of circuit level organization of this receptor system. Building on this groundwork, future studies of these VTA circuits during different behavioral states and tasks related to motivation and cognition will help to elucidate the differences between the normal and dysfunctional NOP-N/OFQ system, improving the potential for therapeutic targeting.

\section{References}

Baker DA, Khroyan TV, O’Dell LE, Fuchs RA, Neisewander JL (1996) Differential effects of intra-accumbens sulpiride on cocaine-induced locomotion and conditioned place preference. J Pharmacol Exp Ther 279:392-401.

Baker DA, Fuchs RA, Specio SE, Khroyan TV, Neisewander JL (1998) Effects of intraaccumbens administration of $\mathrm{SCH}-23390$ on cocaine-induced locomotion and conditioned place preference. Synapse 30:181-193.

Bass CE, Grinevich VP, Kulikova AD, Bonin KD, Budygin EA (2013) Terminal effects of optogenetic stimulation on dopamine dynamics in rat striatum. J Neurosci Methods 214:149-155.

Berthele A, Platzer S, Dworzak D, Schadrack J, Mahal B, Büttner A, Assmus HP, Wurster K, Zieglgänsberger W, Conrad B, Tölle TR (2003) $[3 \mathrm{H}]$-nociceptin ligand-binding and nociceptin opioid receptor mrna expression in the human brain. Neuroscience 121:629640.

Breton JM, Charbit AR, Snyder BJ, Fong PTK, Dias EV, Himmels P, Lock H, Margolis EB (2019) Relative contributions and mapping of ventral tegmental area dopamine and GABA neurons by projection target in the rat. J Comp Neurol 527:916-941.

Britt JP, McGehee DS (2008) Presynaptic opioid and nicotinic receptor modulation of dopamine overflow in the nucleus accumbens. $J$ Neurosci 28:1672-1681.

Brown MTC, Tan KR, O'Connor EC, Nikonenko I, Muller D, Lüscher C (2012) Ventral tegmental area GABA projections pause accumbal cholinergic interneurons to enhance associative learning. Nature 492:452-456.

Bunzow JR, Saez C, Mortrud M, Bouvier C, Williams JT, Low M, Grandy DK (1994) Molecular cloning and tissue distribution of a putative member of the rat opioid receptor gene family that is not a $\mu, \delta$ or $\kappa$ opioid receptor type. FEBS Lett 347:284-288.

Cachope R, Mateo Y, Mathur BN, Irving J, Wang HL, Morales M, Lovinger DM, Cheer JF (2012) Selective activation of cholinergic interneurons enhances accumbal phasic dopamine release: setting the tone for reward processing. Cell Rep 2:33-41.

Chandler DJ, Lamperski CS, Waterhouse BD (2013) Identification and distribution of projections from monoaminergic and cholinergic nuclei to functionally differentiated subregions of prefrontal cortex. Brain Res 1522:38-58.

Ciccocioppo R, Angeletti S, Panocka I, Massi M (2000) Nociceptin/ orphanin FQ and drugs of abuse. Peptides 21:1071-1080.

Ciccocioppo R, Stopponi S, Economidou D, Kuriyama M, Kinoshita H, Heilig M, Roberto M, Weiss F, Teshima K (2014) Chronic treatment with novel brain-penetrating selective NOP receptor agonist MT-7716 reduces alcohol drinking and seeking in the rat. Neuropsychopharmacology 39:2601-2610.

Civelli O, Zhou QY (2008) Orphan G protein-coupled receptors and novel neuropeptides. Results Probl Cell Differ 56:v-vi.

Collins AL, Aitken TJ, Huang IW, Shieh C, Greenfield VY, Monbouquette HG, Ostlund SB, Wassum KM (2019) Nucleus accumbens cholinergic interneurons oppose cue-motivated behavior. Biol Psychiatry 86:388-396.

Connor M, Yeo A, Henderson G (1996) The effect of nociceptin on $\mathrm{Ca} 2+$ channel current and intracellular $\mathrm{Ca} 2+$ in the SH-SY5Y human neuroblastoma cell line. Br J Pharmacol 118:205-207.

Corbani M, Gonindard C, Meunier J-C (2004) Ligand-regulated internalization of the opioid receptor-like 1: a confocal study. Endocrinology 145:2876-2885.

Coull JAM, Boudreau D, Bachand K, Prescott SA, Nault F, Sík A, De Koninck P, De Koninck Y (2003) Trans-synaptic shift in anion gradient in spinal lamina I neurons as a mechanism of neuropathic pain. Nature 424:938-942.

Cox BM, Christie MJ, Devi L, Toll L, Traynor JR (2015) Challenges for opioid receptor nomenclature: IUPHAR review 9. Br J Pharmacol 172:317-323.

Darnieder LM, Melón LC, Do T, Walton NL, Miczek KA, Maguire JL (2019) Female-specific decreases in alcohol binge-like drinking 
resulting from GABA A receptor delta-subunit knockdown in the VTA. Sci Rep 9:8102.

Dautzenberg FM, Wichmann J, Higelin J, Py-Lang G, Kratzeisen C, Malherbe P, Kilpatrick GJ, Jenck F (2001) Pharmacological characterization of the novel nonpeptide orphanin FQ/nociceptin receptor agonist Ro 64-6198: rapid and reversible desensitization of the ORL1 receptor in vitro and lack of tolerance in vivo. J Pharmacol Exp Ther 298:812-819.

Devine DP, Leone P, Pocock D, Wise RA (1993a) Differential involvement of ventral tegmental mu, delta and kappa opioid receptors in modulation of basal mesolimbic dopamine release: in vivo microdialysis studies. J Pharmacol Exp Ther 266:1236-1246.

Devine DP, Leone P, Wise RA (1993b) Mesolimbic dopamine neurotransmission is increased by administration of mu-opioid receptor antagonists. Eur J Pharmacol 243:55-64.

Devine DP, Reinscheid RK, Monsma FJ, Civelli O, Akil H (1996) The novel neuropeptide orphanin FQ fails to produce conditioned place preference or aversion. Brain Res 727:225-229.

Devine DP, Watson SJ, Akil H (2001) Nociceptin/orphanin FQ regulates neuroendocrine function of the limbic-hypothalamic-pituitary-adrenal axis. Neuroscience 102:541-553.

Di Chiara G, Imperato A (1988a) Drugs abused by humans preferentially increase synaptic dopamine concentrations in the mesolimbic system of freely moving rats. Proc Natl Acad Sci USA 85:52745278.

Di Chiara G, Imperato A (1988b) Opposite effects of mu and kappa opiate agonists on dopamine release in the nucleus accumbens and in the dorsal caudate of freely moving rats. J Pharmacol Exp Ther 244:1067-1080.

Di Giannuario A, Pieretti S (2000) Nociceptin differentially affects morphine-induced dopamine release from the nucleus accumbens and nucleus caudate in rats. Peptides 21:1125-1130.

Ebner SR, Roitman MF, Potter DN, Rachlin AB, Chartoff EH (2010) Depressive-like effects of the kappa opioid receptor agonist salvinorin $\mathrm{A}$ are associated with decreased phasic dopamine release in the nucleus accumbens. Psychopharmacology (Berl) 210:241252.

Fenu S, Spina L, Rivas E, Longoni R, Di Chiara G (2006) Morphineconditioned single-trial place preference: role of nucleus accumbens shell dopamine receptors in acquisition, but not expression. Psychopharmacology (Berl) 187:143-153.

Fernandez F, Misilmeri MA, Felger JC, Devine DP (2004) Nociceptin/ orphanin FQ increases anxiety-related behavior and circulating levels of corticosterone during neophobic tests of anxiety. Neuropsychopharmacology 29:59-71.

Ferrini F, Trang T, Mattioli TAM, Laffray S, Del'Guidice T, Lorenzo LE, Castonguay A, Doyon N, Zhang W, Godin AG, Mohr D, Beggs S, Vandal K, Beaulieu JM, Cahill CM, Salter MW, De Koninck Y (2013) Morphine hyperalgesia gated through microglia-mediated disruption of neuronal $\mathrm{Cl}^{-}$homeostasis. Nat Neurosci 16:183-192.

Fields HL, Hjelmstad GO, Margolis EB, Nicola SM (2007) Ventral tegmental area neurons in learned appetitive behavior and positive reinforcement. Annu Rev Neurosci 30:289-316.

Florin S, Suaudeau C, Meunier J-C, Costentin J (1996) Nociceptin stimulates locomotion and exploratory behaviour in mice. Eur $\mathrm{J}$ Pharmacol 317:9-13.

Ford CP, Mark GP, Williams JT (2006) Properties and opioid inhibition of mesolimbic dopamine neurons vary according to target location. J Neurosci 26:2788-2797.

Gavioli EC, Rae GA, Calo' G, Guerrini R, De Lima TCM (2002) Central injections of nocistatin or its C-terminal hexapeptide exert anxiogenic-like effect on behaviour of mice in the plus-maze test. $\mathrm{Br} J$ Pharmacol 136:764-772.

Gintzler AR, Adapa ID, Toll L, Medina VM, Wang L (1997) Modulation of enkephalin release by nociceptin (orphanin FQ). Eur $\mathrm{J}$ Pharmacol 325:29-34.

Goeldner C, Reiss D, Wichmann J, Kieffer BL, Ouagazzal A-M (2009) Activation of nociceptin opioid peptide (NOP) receptor impairs contextual fear learning in mice through glutamatergic mechanisms. Neurobiol Learn Mem 91:393-401.
Gonzalez MC, Kramar CP, Tomaiuolo M, Katche C, Weisstaub N, Cammarota M, Medina JH (2014) Medial prefrontal cortex dopamine controls the persistent storage of aversive memories. Front Behav Neurosci 8:408.

Green MK, Devine DP (2009) Nociceptin/Orphanin FQ and NOP receptor gene regulation after acute or repeated social defeat stress. Neuropeptides 43:507-514.

Green MK, Barbieri EV, Brown BD, Chen K-W, Devine DP (2007) Roles of the bed nucleus of stria terminalis and of the amygdala in N/OFQ-mediated anxiety and HPA axis activation. Neuropeptides 41:399-410.

Hawes BE, Graziano MP, Lambert DG (2000) Cellular actions of nociceptin: transduction mechanisms. Peptides 21:961-967.

Hewitt SA, Wamsteeker JI, Kurz EU, Bains JS (2009) Altered chloride homeostasis removes synaptic inhibitory constraint of the stress axis. Nat Neurosci 12:438-443.

Hiramatsu M, Inoue K (1999) Effects of nocistatin on nociceptin-induced impairment of learning and memory in mice. Eur $\mathrm{J}$ Pharmacol 367:151-155.

Huang S, Borgland SL, Zamponi GW (2019) Dopaminergic modulation of pain signals in the medial prefrontal cortex: challenges and perspectives. Neurosci Lett 702:71-76.

legorova O, Fisyunov A, Krishtal O (2010) G-protein-independent modulation of P-type calcium channels by $\mu$-opioids in Purkinje neurons of rat. Neurosci Lett 480:106-111.

Jenck F, Moreau J-L, Martin JR, Kilpatrick GJ, Reinscheid RK, Monsma FJ, Nothacker H-P, Civelli O (1997) Orphanin FQ acts as an anxiolytic to attenuate behavioral responses to stress. Proc Natl Acad Sci USA 94:14854-14858.

Jinsmaa Y, Takahashi M, Fukunaga H, Yoshikawa M (2000) Retronociceptin methylester, a peptide with analgesic and memory-enhancing activity. Life Sci 67:3095-3101.

Josselyn SA, Beninger RJ (1993) Neuropeptide Y: intraaccumbens injections produce a place preference that is blocked by cis-flupenthixol. Pharmacol Biochem Behav 46:543-552.

Kamei J, Matsunawa Y, Miyata S, Tanaka S, Saitoh A (2004) Effects of nociceptin on the exploratory behavior of mice in the hole-board test. Eur J Pharmacol 489:77-87.

Karkhanis AN, Rose JH, Weiner JL, Jones SR (2016) Early-life social isolation stress increases kappa opioid receptor responsiveness and downregulates the dopamine system. Neuropsychopharmacology 41:2263-2274.

Kim KM, Baratta MV, Yang A, Lee D, Boyden ES, Fiorillo CD (2012) Optogenetic mimicry of the transient activation of dopamine neurons by natural reward is sufficient for operant reinforcement. PLoS One 7:e33612.

Knoflach F, Reinscheid RK, Civelli O, Kemp JA (1996) Modulation of voltage-gated calcium channels by orphanin FQ in freshly dissociated hippocampal neurons. J Neurosci 16:6657-6664.

Koga E, Momiyama T (2000) Presynaptic dopamine D2-like receptors inhibit excitatory transmission onto rat ventral tegmental dopaminergic neurones. J Physiol 523:163-173.

Kuzmin A, Kreek MJ, Bakalkin G, Liljequist S (2007) The nociceptin/orphanin FQ receptor agonist Ro 64-6198 reduces alcohol self-administration and prevents relapse-like alcohol drinking. Neuropsychopharmacology 32:902-910.

Laviolette SR, van der Kooy D (2003) Blockade of mesolimbic dopamine transmission dramatically increases sensitivity to the rewarding effects of nicotine in the ventral tegmental area. Mol Psychiatry 8:50-59, 9.

Leggett JD, Harbuz MS, Jessop DS, Fulford AJ (2006) The nociceptin receptor antagonist [Nphe1,Arg14,Lys15]nociceptin/orphanin FQ$\mathrm{NH} 2$ blocks the stimulatory effects of nociceptin/orphanin $\mathrm{FQ}$ on the HPA axis in rats. Neuroscience 141:2051-2057.

Leggett JD, Jessop DS, Fulford AJ (2007) The nociceptin/orphanin FQ antagonist UFP-101 differentially modulates the glucocorticoid response to restraint stress in rats during the peak and nadir phases of the hypothalamo-pituitary-adrenal axis circadian rhythm. Neuroscience 147:757-764. 
Lutfy K, Do T, Maidment NT (2001) Orphanin FQ/nociceptin attenuates motor stimulation and changes in nucleus accumbens extracellular dopamine induced by cocaine in rats. Psychopharmacology (Berl) 154:1-7.

Ma L, Cheng ZJ, Fan GH, Cai YC, Jiang LZ, Pei G (1997) Functional expression, activation and desensitization of opioid receptor-like receptor ORL1 in neuroblastoma×glioma NG108-15 hybrid cells. FEBS Lett 403:91-94.

Mandyam CD, Altememi GF, Standifer KM (2000) $\beta$-Funaltrexamine inactivates ORL1 receptors in $\mathrm{BE}(2)-\mathrm{C}$ human neuroblastoma cells. Eur J Pharmacol 402:205-207.

Mandyam CD, Thakker DR, Christensen JL, Standifer KM (2002) Orphanin FQ/nociceptin-mediated desensitization of opioid receptor-like 1 receptor and $\mu$ opioid receptors involves protein kinase C: a molecular mechanism for heterologous cross-talk. J Pharmacol Exp Ther 302:502-509.

Margolis EB, Hjelmstad GO, Bonci A, Fields HL (2005) Both kappa and mu opioid agonists inhibit glutamatergic input to ventral tegmental area neurons. J Neurophysiol 93:3086-3093.

Margolis EB, Lock H, Chefer VI, Shippenberg TS, Hjelmstad GO, Fields HL (2006) Kappa opioids selectively control dopaminergic neurons projecting to the prefrontal cortex. Proc Natl Acad Sci USA 103:2938-2942.

Margolis EB, Mitchell JM, Ishikawa J, Hjelmstad GO, Fields HL (2008) Midbrain dopamine neurons: projection target determines action potential duration and dopamine $\mathrm{D}(2)$ receptor inhibition. $J$ Neurosci 28:8908-8913.

Margolis EB, Mitchell JM, Hjelmstad GO, Fields HL (2011) A novel opioid receptor-mediated enhancement of GABAA receptor function induced by stress in ventral tegmental area neurons. J Physiol 589:4229-4242.

Margolis EB, Hjelmstad GO, Fujita W, Fields HL (2014) Direct bidirectional $\mu$-opioid control of midbrain dopamine neurons. J Neurosci 34:14707-14716.

Margolis EB, Fujita W, Devi LA, Fields HL (2017) Two delta opioid receptor subtypes are functional in single ventral tegmental area neurons, and can interact with the mu opioid receptor. Neuropharmacology 123:420-432.

McCutcheon JE, Ebner SR, Loriaux AL, Roitman MF (2012) Encoding of aversion by dopamine and the nucleus accumbens. Front Neurosci 6:137.

Meng F, Taylor LP, Hoversten MT, Ueda Y, Ardati A, Reinscheid RK, Monsma FJ, Watson SJ, Civelli O, Akil H (1996) Moving from the orphanin $F Q$ receptor to an opioid receptor using four point mutations. J Biol Chem 271:32016-32020.

Meunier JC, Mollereau C, Toll L, Suaudeau C, Moisand C, Alvinerie $\mathrm{P}$, Butour JL, Guillemot JC, Ferrara P, Monsarrat B, Mazarguil H, Vassart G, Parmentier M, Costentin J (1995) Isolation and structure of the endogenous agonist of opioid receptor-like ORL1 receptor. Nature 377:532-535.

Mogil JS, Pasternak GW (2001) The molecular and behavioral pharmacology of the orphanin $\mathrm{FQ} /$ nociceptin peptide and receptor family. Pharmacol Rev 53:381-415.

Mohebi A, Pettibone JR, Hamid AA, Wong J-MT, Vinson LT, Patriarchi T, Tian L, Kennedy RT, Berke JD (2019) Dissociable dopamine dynamics for learning and motivation. Nature 570:65-70.

Mollereau C, Parmentier M, Mailleux P, Butour JL, Moisand C, Chalon P, Caput D, Vassart G, Meunier JC (1994) ORL1, a novel member of the opioid receptor family. Cloning, functional expression and localization. FEBS Lett 341:33-38.

Morales M, Margolis EB (2017) Ventral tegmental area: cellular heterogeneity, connectivity and behaviour. Nat Rev Neurosci 18:73-85.

Morutto SL, Phillips GD (1998) Interactions between sulpiride infusions within the perifornical region of the lateral hypothalamus and the nucleus accumbens on measures of locomotor activity and conditioned place preference. Behav Pharmacol 9:345-355.

Murphy NP, Maidment NT (1999) Orphanin FQ/nociceptin modulation of mesolimbic dopamine transmission determined by microdialysis. J Neurochem 73:179-186.
Murphy NP, Ly HT, Maidment NT (1996) Intracerebroventricular orphanin FQ/Nociceptin supresses dopamine release in the nucleus accumbens of anaesthetized rats. Neuroscience 75:1-4.

Nagai J, Kurokawa M, Takeshima H, Kieffer BL, Ueda H (2007) Circadian-dependent learning and memory enhancement in nociceptin receptor-deficient mice with a novel KUROBOX apparatus using stress-free positive cue task. J Pharmacol Exp Ther 321:195-201.

Nativio P, Pascale E, Maffei A, Scaccianoce S, Passarelli F (2012) Effect of stress on hippocampal nociceptin expression in the rat. Stress 15:378-384.

Neal CR, Mansour A, Reinscheid R, Nothacker HP, Civelli O, Akil H, Watson SJ (1999) Opioid receptor-like (ORL1) receptor distribution in the rat central nervous system: comparison of ORL1 receptor mRNA expression with (125)I-[(14)Tyr]-orphanin FQ binding. J Comp Neurol 412:563-605.

New DC, Wong YH (2002) The ORL 1 receptor: molecular pharmacology and signalling mechanisms. Neurosignals 11:197-212.

Nicholson JR, Akil H, Watson SJ (2002) Orphanin FQ-induced hyperphagia is mediated by corticosterone and central glucocorticoid receptors. Neuroscience 115:637-643.

Noda Y, Mamiya T, Nabeshima T (1999) [Behavioral pharmacological characterization of mice lacking the nociceptin receptor]. Nihon Shinkei Seishin Yakurigaku Zasshi 19:73-78.

Onali P, Olianas MC (1991) Naturally occurring opioid receptor agonists stimulate adenylate cyclase activity in rat olfactory bulb. Mol Pharmacol 39:436-441.

O'Neill B, Patel JC, Rice ME (2017) Characterization of optically and electrically evoked dopamine release in striatal slices from digenic knock-in mice with DAT-driven expression of channelrhodopsin. ACS Chem Neurosci 8:310-319.

Ostroumov A, Thomas AM, Kimmey BA, Karsch JS, Doyon WM, Dani JA (2016) Stress increases ethanol self-administration via a shift toward excitatory GABA signaling in the ventral tegmental area. Neuron 92:493-504.

Ott T, Nieder A (2019) Dopamine and cognitive control in prefrontal cortex. Trends Cogn Sci 23:213-234.

Parker KE, Pedersen CE, Gomez AM, Spangler SM, Walicki MC, Feng SY, Stewart SL, Otis JM, Al-Hasani R, McCall JG, Sakers K, Bhatti DL, Copits BA, Gereau RW, Jhou T, Kash TJ, Dougherty JD, Stuber GD, Bruchas MR (2019) A paranigral VTA nociceptin circuit that constrains motivation for reward. Cell 178:653-671.e19.

Paxinos G, Watson C (1997) The rat brain in stereotaxic coordinates, compact, Ed 3. San Diego: Academic Press.

Puig MV, Antzoulatos EG, Miller EK (2014) Prefrontal dopamine in associative learning and memory. Neuroscience 282:217-229.

Puri SK, Cochin J, Volicer L (1975) Effect of morphine sulfate on adenylate cyclase and phosphodiesterase activities in rat corpus striatum. Life Sci 16:759-767.

Qi J, Zhang S, Wang HL, Barker DJ, Miranda-Barrientos J, Morales M (2016) VTA glutamatergic inputs to nucleus accumbens drive aversion by acting on GABAergic interneurons. Nat Neurosci 19:725-733.

Reinscheid RK, Nothacker H-P, Bourson A, Ardati A, Henningsen RA, Bunzow JR, Grandy DK, Langen H, Monsma FJ, Civelli O (1995) Orphanin FQ: a neuropeptide that activates an opioidlike G protein-coupled receptor. Science 270:792-794.

Reinscheid RK, Ardati A, Monsma FJ, Civelli O (1996) Structure-activity relationship studies on the novel neuropeptide orphanin $F Q$. J Biol Chem 271:14163-14168.

Robble MA, Bozsik ME, Wheeler DS, Wheeler RA (2020) Learned avoidance requires VTA KOR-mediated reductions in dopamine. Neuropharmacology 167:107996.

Rorick-Kehn LM, Ciccocioppo R, Wong CJ, Witkin JM, Martinez-Grau MA, Stopponi S, Adams BL, Katner JS, Perry KW, Toledo MA, Diaz N, Lafuente C, Jiménez A, Benito A, Pedregal C, Weiss F, Statnick MA (2016) A novel, orally bioavailable nociceptin receptor antagonist, LY2940094, reduces ethanol self-administration and ethanol seeking in animal models. Alcohol Clin Exp Res 40:945-954. 
Sakoori K, Murphy NP (2004) Central administration of nociceptin/orphanin FQ blocks the acquisition of conditioned place preference to morphine and cocaine, but not conditioned place aversion to naloxone in mice. Psychopharmacology (Berl) 172:129-136.

Sandin J, Ogren SO, Terenius L (2004) Nociceptin/orphanin FQ modulates spatial learning via ORL-1 receptors in the dorsal hippocampus of the rat. Brain Res 997:222-233.

Santos LEC, Rodrigues AM, Lopes MR, Costa VDC, Scorza CA, Scorza FA, Cavalheiro EA, Almeida A-CG (2017) Long-term alcohol exposure elicits hippocampal nonsynaptic epileptiform activity changes associated with expression and functional changes in NKCC1, KCC2 cotransporters and $\mathrm{Na}+/ \mathrm{K}+-$-ATPase. Neuroscience 340:530-541.

Shippenberg TS, Bals-Kubik R (1995) Involvement of the mesolimbic dopamine system in mediating the aversive effects of opioid antagonists in the rat. Behav Pharmacol 6:99-106.

Shippenberg TS, Bals-Kubik R, Huber A, Herz A (1991) Neuroanatomical substrates mediating the aversive effects of D-1 dopamine receptor antagonists. Psychopharmacology (Berl) 103:209-214.

Sim LJ, Xiao R, Childers SR (1996) Identification of opioid receptorlike (ORL1) peptide-stimulated [35S]GTP gamma $S$ binding in rat brain. Neuroreport 7:729-733.

Spampinato S, Di Toro R, Qasem AR (2001) Nociceptin-induced internalization of the ORL1 receptor in human neuroblastoma cells. Neuroreport 12:3159-3163.

Spampinato S, Di Toro R, Alessandri M, Murari G (2002) Agonist-induced internalization and desensitization of the human nociceptin receptor expressed in CHO cells. Cell Mol Life Sci 59:2172-2183.

Spanagel R, Herz A, Shippenberg TS (1992) Opposing tonically active endogenous opioid systems modulate the mesolimbic dopaminergic pathway. Proc Natl Acad Sci USA 89:2046-2050.

Spina L, Fenu S, Longoni R, Rivas E, Di Chiara G (2006) Nicotineconditioned single-trial place preference: selective role of nucleus accumbens shell dopamine D1 receptors in acquisition. Psychopharmacology (Berl) 184:447-455.

Tepper JM, Trent F, Nakamura S (1990) Postnatal development of the electrical activity of rat nigrostriatal dopaminergic neurons. Brain Res Dev Brain Res 54:21-33.

Thakker DR, Standifer KM (2002) Induction of G protein-coupled receptor kinases 2 and 3 contributes to the cross-talk between $\mu$ and ORL1 receptors following prolonged agonist exposure. Neuropharmacology 43:979-990.

Toledo MA, Pedregal C, Lafuente C, Diaz N, Martinez-Grau MA, Jiménez A, Benito A, Torrado A, Mateos C, Joshi EM, Kahl SD, Rash KS, Mudra DR, Barth VN, Shaw DB, McKinzie D, Witkin JM, Statnick MA (2014) Discovery of a novel series of orally active nociceptin/orphanin FQ (NOP) receptor antagonists based on a dihydrospiro(piperidine-4,7'-thieno[2,3-c]pyran) scaffold. J Med Chem 57:3418-3429.

Toll L, Bruchas MR, Calo' G, Cox BM, Zaveri NT (2016) Nociceptin/ orphanin FQ receptor structure, signaling, ligands, functions, and interactions with opioid systems. Pharmacol Rev 68:419-457.

Tsai HC, Zhang F, Adamantidis A, Stuber GD, Bonci A, de Lecea L, Deisseroth K (2009) Phasic firing in dopaminergic neurons is sufficient for behavioral conditioning. Science 324:1080-1084.

Tzschentke TM (2001) Pharmacology and behavioral pharmacology of the mesocortical dopamine system. Prog Neurobiol 63:241-320.

Ungerstedt U (1971) Stereotaxic mapping of the monoamine pathways in the rat brain. Acta Physiol Scand Suppl 367:1-48.
Varty GB, Lu SX, Morgan CA, Cohen-Williams ME, Hodgson RA, Smith-Torhan A, Zhang H, Fawzi AB, Graziano MP, Ho GD, Matasi J, Tulshian D, Coffin VL, Carey GJ (2008) The anxiolytic-like effects of the novel, orally active nociceptin opioid receptor agonist 8-[bis (2-methylphenyl)methyl]-3-phenyl-8-azabicyclo[3.2.1]octan-3-ol (SCH 221510). J Pharmacol Exp Ther 326:672-682.

Vaughan CW, Christie MJ (1996) Increase by the ORL1 receptor (opioid receptor-like1) ligand, nociceptin, of inwardly rectifying $\mathrm{K}$ conductance in dorsal raphe nucleus neurones. $\mathrm{Br} \mathrm{J}$ Pharmacol 117:1609-1611.

Vazquez-DeRose J, Stauber G, Khroyan TV, Xie X(S), Zaveri NT, Toll L (2013) Retrodialysis of N/OFQ into the nucleus accumbens shell blocks cocaine-induced increases in extracellular dopamine and locomotor activity. Eur J Pharmacol 699:200-206.

Vitale G, Arletti R, Ruggieri V, Cifani C, Massi M (2006) Anxiolytic-like effects of nociceptin/orphanin FQ in the elevated plus maze and in the conditioned defensive burying test in rats. Peptides 27:2193-2200.

Walker JR, Spina M, Terenius L, Koob GF (1998) Nociceptin fails to affect heroin self-administration in the rat. Neuroreport 9:2243-2247.

Walsh JP, Cepeda C, Buchwald NA, Levine MS (1991) Neurophysiological maturation of cat substantia nigra neurons: evidence from in vitro studies. Synapse 7:291-300.

Wang JB, Johnson PS, Imai Y, Persico AM, Ozenberger BA, Eppler CM, Uhl GR (1994) cDNA Cloning of an orphan opiate receptor gene family member and its splice variant. FEBS Lett 348:75-79.

Wang L, Pitts DK (1995) Ontogeny of nigrostriatal dopamine neuron autoreceptors: iontophoretic studies. J Pharmacol Exp Ther 272:164-176.

Werling LL, Frattali A, Portoghese PS, Takemori AE, Cox BM (1988) Kappa receptor regulation of dopamine release from striatum and cortex of rats and guinea pigs. J Pharmacol Exp Ther 246:282-286.

Winter S, Dieckmann M, Schwabe K (2009) Dopamine in the prefrontal cortex regulates rats behavioral flexibility to changing reward value. Behav Brain Res 198:206-213.

Wise RA (2005) Forebrain substrates of reward and motivation. J Comp Neurol 493:115-121.

Witkin JM, Wallace TL, Martin WJ (2019) Therapeutic approaches for NOP receptor antagonists in neurobehavioral disorders: clinical studies in major depressive disorder and alcohol use disorder with BTRX-246040 (LY2940094). Handb Exp Pharmacol 254:399-415.

Witten IB, Steinberg EE, Lee SY, Davidson TJ, Zalocusky KA, Brodsky M, Yizhar O, Cho SL, Gong S, Ramakrishnan C, Stuber GD, Tye KM, Janak PH, Deisseroth K (2011) Recombinase-driver rat lines: tools, techniques, and optogenetic application to dopamine-mediated reinforcement. Neuron 72:721-733.

Xiao C, Shao XM, Olive MF, Griffin WC 3rd, Li KY, Krnjević K, Zhou C, Ye $\mathrm{JH}$ (2009) Ethanol facilitates glutamatergic transmission to dopamine neurons in the ventral tegmental area. Neuropsychopharmacology 34:307-318.

Zhang NR, Planer W, Siuda ER, Zhao H-C, Stickler L, Chang SD, Baird MA, Cao Y-Q, Bruchas MR (2012) Serine 363 is required for nociceptin/orphanin FQ opioid receptor (NOPR) desensitization, internalization, and arrestin signaling. J Biol Chem 287:4201942030.

Zheng F, Grandy DK, Johnson SW (2002) Actions of orphanin FQ/nociceptin on rat ventral tegmental area neurons in vitro. $\mathrm{Br} J$ Pharmacol 136:1065-1071. 